\title{
Panicoideae (Poaceae) em remanescentes florestais do sul da Bahia: aspectos taxonômicos e ecológicos ${ }^{1}$
}

\author{
Panicoideae (Poaceae) from forest remnants at the Southern Bahia: \\ taxonomic and ecological aspects
}

Karena Mendes Pimenta ${ }^{2,3}$, Marcos da Costa Dórea ${ }^{2}$ \& Reyjane Patrícia de Oliveira ${ }^{2}$

\begin{abstract}
Resumo
Esse trabalho consiste no levantamento das espécies de Panicoideae (Poaceae) em remanescentes de Mata Atlântica no sul do estado da Bahia. As coletas foram realizadas entre os anos de 2007 e 2010 , concentrando-se nos bordos e no interior dos três maiores remanescentes florestais da Reserva Ecológica da Michelin (Mata da Vila 5, Pancada Grande e Pacangê). Foram confirmadas 24 espécies em 11 gêneros, sendo Ichnanthus $\mathrm{P}$. Beauv. e Paspalum L. os mais representativos, com cinco e oito espécies, respectivamente. Uma chave de identificação para gêneros e espécies é apresentada, assim como descrições, ilustrações e dados ecológicos, contribuindo para o conhecimento das espécies florestais de Poaceae do Brasil.
\end{abstract}

Palavras-chave: Gramineae, florística, Mata Atlântica.

\begin{abstract}
We present a floristic survey of Panicoideae (Poaceae) in remnants of Atlantic Forest in Southern Bahia State, Brazil, in the Michelin Ecological Reserve. Collections were made from 2007 to 2010, focusing on the borders and interior of the three major forest fragments (Vila 5, Pancada Grande and Pacangê). Twenty four species in 11 genera were found, being Ichnanthus P. Beauv. and Paspalum L. the most representative, with five and eight species, respectively. An identification key to genera and species is presented, as well as descriptions, illustrations and ecological data, increasing the knowledge on Poaceae from Brazilian forests. Key words: Gramineae, floristic survey, Atlantic Forest.
\end{abstract}

\section{Introdução}

Poaceae é uma família cosmopolita de monocotiledôneas, que inclui atualmente cerca de 10.000 espécies reunidas em 700 gêneros (GPWG 2001). Está organizada em 12 subfamílias, sendo Panicoideae a maior delas, com 220 gêneros e cerca de 3.300 espécies (Sánchez-Ken \& Clark 2010). Esta subfamília representa um grupo monofilético, com espiguetas bifloras, das quais a inferior é geralmente estaminada ou neutra e a superior bissexuada, além do distintivo grão de amido que possui (Giussani et al. 2001).

Com base em evidências moleculares, Sánchez-Ken \& Clark (2010) incluíram os membros de Centhothecoideae na delimitação de Panicoideae, e esses autores também reconheceram 12 tribos para essa subfamília, sendo Paniceae e Andropogoneae aquelas que incluíam o maior numero de gêneros e espécies. Mais recentemente, a tribo Paniceae teve sua circunscrição revisada, estando atualmente dividida em duas tribos: Paniceae (s.s) e Paspaleae (Morrone et al. 2012).

No Catálogo de Plantas e Fungos do Brasil foram indicados 204 gêneros e 1.401 espécies de Poaceae (Filgueiras et al. 2012), dos quais 91 gêneros e 772 espécies pertencem a Panicoideae, com grande representatividade em ambientes florestais no país. Na Bahia, os estudos com Poaceae foram iniciados por Renvoize (1984), cuja obra inclui a mais completa lista da família para o estado. Dentre as quase 300 espécies citadas por esse autor, boa parte ocorre ao longo das regiões costeiras, dentro dos limites do bioma Mata Atlântica.

\footnotetext{
${ }^{1}$ Monografia de graduação da primeira autora.

${ }^{2}$ Universidade Estadual de Feira de Santana, Depto. Ciências Biológicas, Programa de Pós-graduação em Botânica, BR 116N km 3, 44031-460, Feira de Santana, Bahia, Brasil.

${ }^{3}$ Autor para correspondência: karenamendes@hotmail.com
} 
Estudos florísticos subsequentes têm indicado várias novas espécies para Bahia, especialmente para a Mata Atlântica do sul do Estado (Oliveira 2001; Oliveira et al. 2004, 2008; Oliveira \& Longhi-Wagner 2005; Mota 2009; Mota \& Oliveira 2012). Entretanto, a maioria dos trabalhos tem enfocado membros da subfamília Bambusoideae e, por isso, Panicoideae ainda é um grupo pouco conhecido nesses ambientes florestais.

Apesar de todo o potencial para estudos em biodiversidade, ainda existem áreas pouco amostradas na Bahia, inclusive dentro dos limites do bioma Mata Atlântica. Assim, visando aumentar o conhecimento sobre os representantes de Poaceae nas florestas do estado, é aqui apresentado um levantamento da subfamília Panicoideae em um importante remanescente de Mata Atlântica na microrregião Litoral Sul da Bahia: a Reserva Ecológica da Michelin.

\section{Material e Métodos}

A Reserva Ecológica da Michelin (REM), criada em 2005, está incluída na microrregião Litoral Sul do estado da Bahia, em uma área popularmente conhecida como Costa do Dendê. Está localizada entre os municípios de Ituberá e Igrapiúna (Fig. 1), nas coordenadas $13^{\circ} 49^{\prime} \mathrm{S}$ e $39^{\circ} 8^{\prime} \mathrm{W}$, sendo dividida em três principais remanescentes florestais: Mata da Vila 5 (ca. 180 ha), Pacangê (ca. 550 ha) e Pancada Grande (ca. 172 ha) (Fig. 2). A Reserva é permanente sendo seu uso limitado à pesquisa, educação ambiental e turismo controlado. Abrange ca. 3.096 ha, com precipitação média de $2.051 \mathrm{~mm}$ e temperaturas entre $18^{\circ} \mathrm{e} 30^{\circ} \mathrm{C}$. É composta por diversos ambientes do bioma Mata Atlântica, incluindo importantes remanescentes de floresta ombrófila (Boas-Bastos \& Bastos 2009), principal componente dos remanescentes florestais estudados.

Foram realizadas expedições mensais para a área de estudos, entre agosto de 2007 e janeiro de 2010, com amostragem nos três remanescentes florestais mencionados. A amostragem foi feita nos bordos e no interior dos mesmos, principalmente ao longo das trilhas. Os espécimes foram depositados no herbário HUEFS, e duplicatas foram enviadas aos herbários ALCB e CEPEC (acrônimos segundo Thiers 2012).

Para a identificação dos espécimes foram selecionados materiais representativos de cada área, e foram utilizadas chaves para gêneros e espécies de Poaceae, especialmente Renvoize (1984),

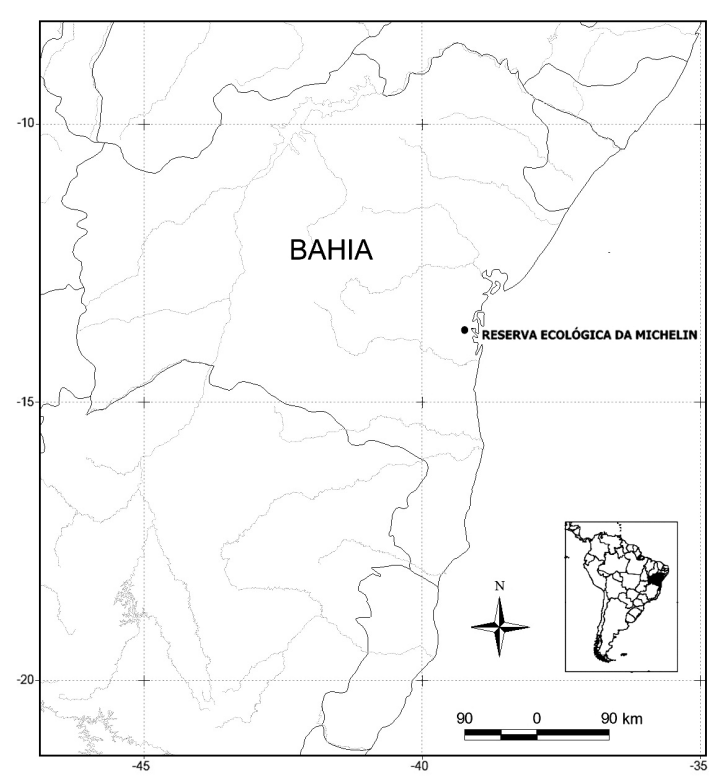

Figura 1 - Localização da área de estudos (Reserva Ecológica da Michelin, entre os municípios de Ituberá e Igrapiúna, na microrregião Litoral Sul da Bahia, Brasil). Figure 1- Map of study area (Michelin Ecological Reserve, between Ituberá and Igrapiúna municipalities, Southern Bahia, Brazil).

Longhi-Wagner (2001) e Mota \& Oliveira (2011). As descrições e ilustrações incluíram os caracteres considerados mais úteis taxonomicamente. Os dados citados sobre distribuição geográfica e aspectos ecológicos das espécies foram obtidos através da literatura, etiquetas dos materiais depositados em herbário e informações das coletas realizadas durante o trabalho.

\section{Resultados e Discussão}

Foram listadas para a área de estudos 24 espécies da subfamília Panicoideae, incluídas em 11 gêneros. Destes, apenas um pertence à tribo Zeugiteae (Ortochlada P.Beauv \& C.E.Hubb.), um à tribo Andropogoneae (Andropogon L.), e os demais, pertencem à tribo Paniceae $s$. $l$.

Com base na nova classificação para esse grupo (Morrone et al. 2012), pertencem à tribo Paspaleae: Homolepis Chase, Ichnanthus P. Beauv., Paspalum L. e Steinchisma Raf., além de Panicum pilosum Sw. (Panicum sect. Laxa); e o restante está incluído em Paniceae s.s. (Dichanthelium (Hitchc. \& Chase) Gould, Digitaria Haller, Lasiacis (Griseb.) Hitchc., Sacciolepis Nash), além de Panicum brevifolium L., que permanece insertae sedis. 

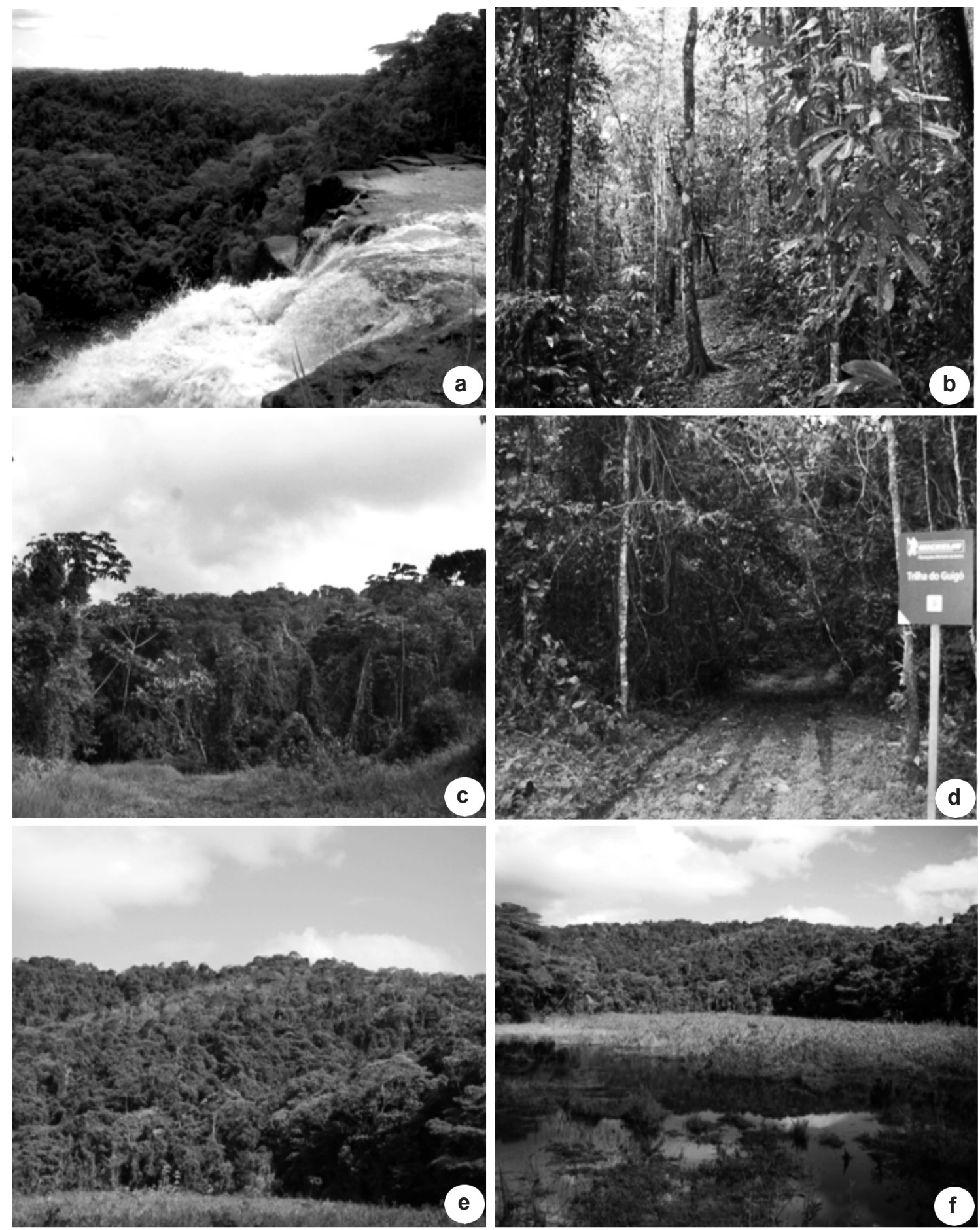

Figura 2 - a-f. Remanescentes florestais estudados na Reserva Ecológica da Michelin - a-b. Pancada Grande, c-d. Vila 5, e-f. Pacangê.

Figure 2 - a-f. Forest remnants studied in the Reserva Ecológica da Michelin Southern Bahia, Brazil - a-b. Pancada Grande, c-d. Vila 5, e-f. Pacangê. 
Dentre esses gêneros, Paspalum foi mais representativo na área, incluindo oito espécies, seguido de Ichnanthus, com cinco espécies e maior ocorrência entre os remanescentes florestais estudados, com pelo menos três espécies em duas das três áreas.

\section{Chave para os gêneros e espécies de Panicoideae ocorrentes nos remanescentes florestais da Reserva Ecológica da Michelin}

1. Inflorescência corimbiforme, plumosa; espatéola conspícua, com dois ramos floríferos cada

1'. Inflorescência não corimbiforme, não plumosa; espatéola ausente.

1. Andropogon bicornis

2. Espiguetas oblíquas nos pedicelos

6. Lasiacis ligulata

2'. Sem espiguetas oblíquas nos pedicelos.

3. Antécio superior com um par de apêndices aliformes, cicatrizes ou protuberâncias na base do lema 5. Ichnanthus

3'. Antécio superior sem um par de apêndices aliformes, cicatrizes ou protuberâncias na base do lema. 4. Inflorescência racemosa.

5. Antécio superior lanceolado, com ápice acuminado, margens do lema expandidas e hialinas envolvendo a pálea .....

5'. Antécio superior oboval, nunca lanceolado, com ápice obtuso nunca acuminado ou aristado, lema sem margens expandidas e hialinas envolvendo a pálea

9. Paspalum

4'. Inflorescência paniculada, aberta ou espiciforme.

6. Panícula espiciforme 10. Sacciolepis indica

6'. Panícula aberta.

7. Lâmina foliar com pseudopecíolo

7. Orthoclada laxa

7'. Lâmina foliar séssil.

8. Pálea inferior conspícua, expandida na maturação

11. Steinchisma laxa

8'. Pálea inferior ausente ou não expandida na maturação.

9. Glumas subiguais ao comprimento da espigueta

4. Homolepis aturensis

9'. Glumas menores que o comprimento da espigueta.

10. Gluma superior 7-nervada, lema superior curtamente apiculado, papiloso em toda a sua extensão.....

2. Dichanthelium

10'. Gluma superior 5-nervada, lema superior não apiculado, antécio superior sem papilas 8. Panicum

1. Andropogon L., Sp. Pl. 2: 1045. 1753.

Andropogon inclui ca. 100 espécies, distribuídas em regiões tropicais e subtropicais do mundo, das quais 28 ocorrem no Brasil (Zanin 2012). Nos remanescentes florestais da área de estudo, está representado por apenas uma espécie.

\subsection{Andropogon bicornis L., Pl. 2: 1046. 1753.}

Fig. 3a-b, 8a

Plantas cespitosas, $98-100 \mathrm{~cm}$ compr. Folhas com bainhas glabras, margens não ciliadas, sésseis; lígula membranosa; lâminas 24,5-38 × 3-4 cm, lineares, ápice agudo, base truncada, face adaxial pubescente na base, face abaxial glabra. Inflorescências 22-30 cm compr., corimbiformes, plumosas; espatéolas conspícuas, com dois ramos floríferos cada. Espiguetas 2,5-3 × 0,5 $\mathrm{mm}$, pareadas, uma séssil e a outra pedicelada, linear-lanceoladas, múticas; gluma inferior da espigueta séssil 2-nervada, escabra no ápice sobre as nervuras; a superior 1-nervada, escabra no ápice sob as nervuras; antécio inferior neutro; antécio superior 1,7-2 ×0,5 mm, lanceolado, ápice agudo, glabro, liso, estramíneo. Cariopse 1,8-2 $\times 0,3 \mathrm{~mm}$, castanha, sem manchas.

Material selecionado: Igrapiúna. Mata da Vila 5, 1.I.2008, fl., K.M. Pimenta 30 (HUEFS). 

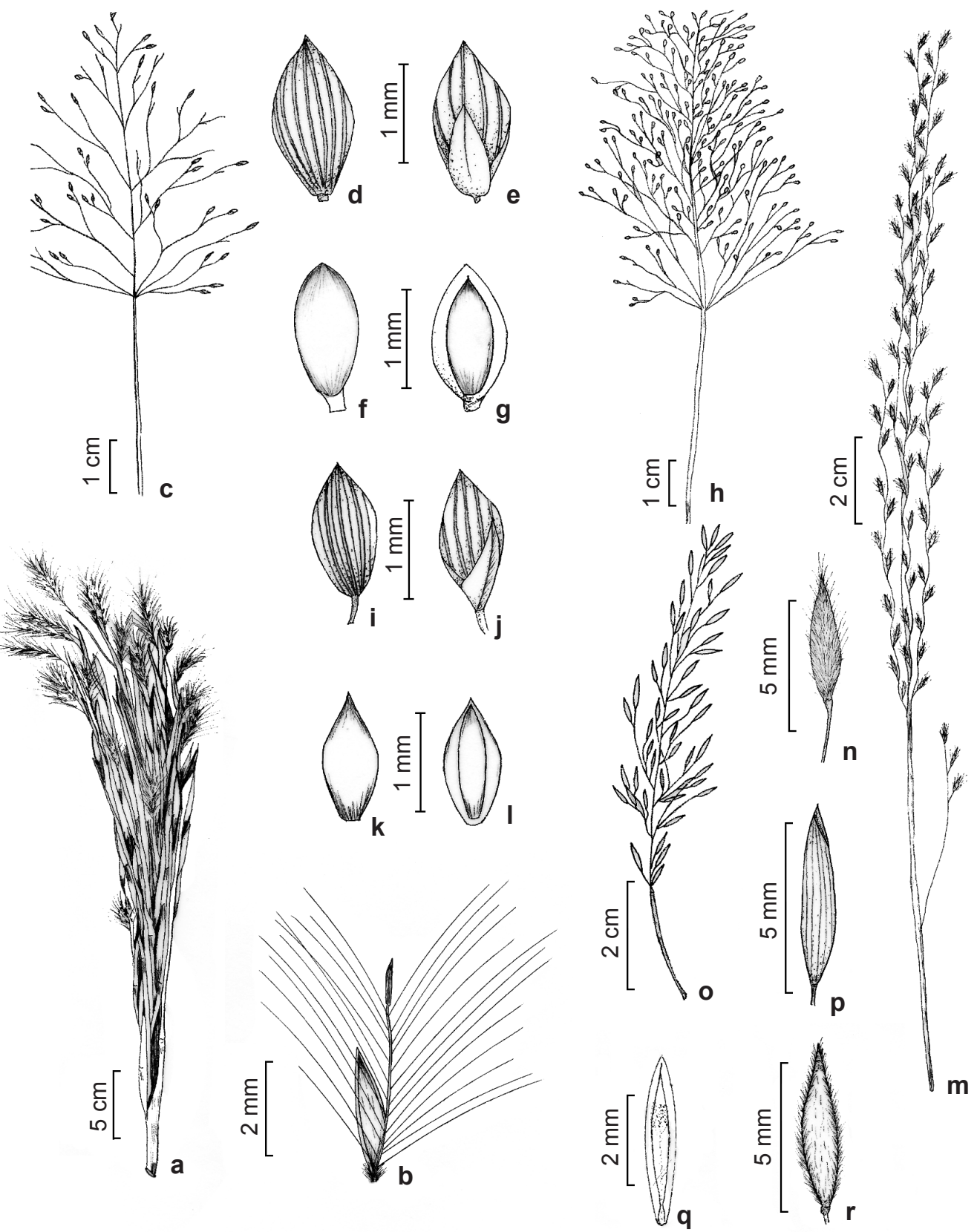

Figura 3 - a-b. Andropogon bicornis L. - a. inflorescência; b. espigueta (K.M. Pimenta et al. 30). c-g. Dichanthelium aequivaginatum (Swallen) Zuloaga -c. inflorescência; d. espigueta, vista da gluma superior; e. espigueta, vista da gluma inferior; f. antécio superior, vista da pálea; g. antécio superior, vista do lema (K.M. Pimenta et al. 130). h-k. D. sciurotoides (Zuloaga \& Morrone) Davidse - h. inflorescência; i. espigueta, vista da gluma superior; j. espigueta, vista lateral da gluma inferior; $\mathrm{k}$. antécio superior, vista da pálea; 1. antécio superior vista da pálea (K.M. Pimenta et al. 125). m-n. Digitaria insularis (L.) Fedde $-\mathrm{m}$. inflorescência; $\mathrm{n}$. espigueta (R.P. Oliveira et al. 1406). o-r. Homolepis aturensis (Kunth) Chase - o. inflorescência; $\mathrm{p}$. espigueta, vista da gluma inferior; q. lema inferior piloso; r. antécio superior, vista do lema (K.M. Pimenta et al. 158).

Figure 3 - a-b. Andropogon bicornis L. - a. inflorescence; b. spikelet (K.M. Pimenta et al. 30). c-g. Dichanthelium aequivaginatum (Swallen) Zuloaga - c. inflorescence; d. spikelet, view of the upper glume; e. spikelets, view of the lower glume; $f$. upper anthecium, view of palea; g. upper anthecium, view of the lemma (K.M. Pimenta et al. 130). h-1.D. sciuritoides (Zuloaga \& Morrone) Davidse -h. inflorescence; i. spikelet, view of the upper glume; $j$. spikelet, lateral view of the lower glume; $\mathrm{k}$. upper anthecium, view of the palea; 1 . upper anthecium, view of the palea (K.M. Pimenta et al. 125). m-n. Digitaria insularis (L.) Fedde - m. inflorescence; $\mathrm{n}$. spikelet (R.P. Oliveira et al. 1406). o-r. Homolepis aturensis (Kunth) Chase - o. inflorescence; p. spikelet, view of the lower glume; q. lower pilose lemma; r. upper anthecium, view of the lemma (K.M. Pimenta et al. 158). 
Andropogon bicornis é encontrada do México até a Argentina (Zuloaga et al. 2003). Ocorre nos bordos da mata da Vila 5, geralmente em locais alterados. Encontrada fértil no período de dezembro a fevereiro. Possui inflorescência corimbiforme, densamente pilosa, com aspecto plumoso, caráter pelo qual se diferencia claramente das demais espécies de Panicoideae da área de estudos.
2. Dichanthelium (Hitchc. \& Chase) Gould, Brittonia 26(1): 56. 1974.

Dichanthelium inclui 55 espécies, ocorrendo no Canadá, Estados Unidos, América Central e do Sul (Aliscioni et al. 2003). São citadas 27 espécies para o Brasil (Viana \& Rodrigues 2012), das quais duas ocorrem na área de estudos.

\section{Chave para as espécies de Dichanthelium ocorrentes na Reserva Ecológica da Michelin}

1. Lâminas foliares glabras em ambas as faces; espiguetas com gluma inferior 3-nervada; antécio superior 1,7-1,8 mm compr., elíptico 2.1. D. aequivaginatum

1'. Lâminas foliares pilosas em ambas as faces; espiguetas com gluma inferior 1-nervada; antécio superior 1,3-1,5 mm compr., oval-lanceolado

2.2. D. sciurotoides

2.1. Dichanthelium aequivaginatum (Swallen) Zuloaga, Amer. J. Bot. 90: 816. 2003. Fig. 3c-g Plantas decumbentes, 54-56 cm compr. Folhas com bainhas glabras a esparsamente pilosas, margens ciliadas, sésseis; lígula membranosociliada; lâminas 6,5-9,8 ×0,9-2,5 cm, lanceoladas, ápice agudo, base arredondada, glabras em ambas as faces. Inflorescências 7-8 cm compr., paniculadas, abertas, sem ramos emaranhados. Espiguetas 1,7-2 $\times 0,7-1 \mathrm{~mm}$, pareadas, ambas pediceladas, elípticas; glumas curto-escabras, a inferior menor que o comprimento da espigueta, 3-nervada; a superior subigual ao comprimento da espigueta, 7-nervada; antécio inferior neutro; antécio superior 1,7-1,8 $\times 0,7 \mathrm{~mm}$, elíptico, apiculado, glabro, papiloso, estramíneo. Cariopse ca. 1,2 mm compr., castanha, com uma mancha marrom na base.

Material selecionado: Igrapiúna, Mata da Vila 5, 29.VII.2008, fl., K.M. Pimenta 130 (HUEFS).

Dichanthelium aequivaginatum é encontrada no Brasil, Guiana e Venezuela (Zuloaga et al. 2003). Ocorre no interior do remanescente da Vila 5, ao longo das trilhas. Encontrada fértil apenas em julho. Além de apresentar lâmina foliares glabras e gluma inferior 3-nervada (vs. lâminas pilosas e gluma inferior 3-nervada) diferencia-se de D. sciurotoides também pelas inflorescências sem ramos emaranhados. Porém, nos espécimes da área de estudos, as lâminas foliares são glabras e a gluma inferior 3-nervada.

\subsection{Dichanthelium sciurotoides (Zuloaga \& Morrone)} Davidse, Novon 2(2): 104. 1992.

Fig. 3h-1

Plantas decumbentes, $42-45 \mathrm{~cm}$ compr. Folhas com bainhas glabras, margens ciliadas, sésseis; lígula membranoso-ciliada; lâminas 4-11 ×0,9-2,5 cm, lanceoladas, ápice agudo, base subcordada, pilosas em ambas as faces. Inflorescências $7-8 \mathrm{~cm}$ compr., paniculadas, abertas, com ramos emaranhados. Espiguetas $1,7-2 \times 0,5 \mathrm{~mm}$, pareadas, ambas pediceladas, lanceoladas; glumas curto-escabras, a inferior menor que o comprimento da espigueta, 1-nervada; a superior subigual o comprimento da espigueta, 7-nervada; antécio inferior neutro; antécio superior 1,3-1,5×0,5 mm, oval-lanceolado, apiculado, glabro, papiloso, estramíneo. Cariopse ca. $1 \mathrm{~mm}$ compr., castanha, sem manchas.

Material selecionado: Igrapiúna. Mata da Vila 5, 29.VII. 2008, fl., K.M. Pimenta 125 (HUEFS).

Dichanthelium sciurotoides é encontrada em Belize, Bolívia, Brasil, Equador, Guiana Francesa, Guiana, Nicarágua, Panamá e Venezuela (Zuloaga et al. 2003). Ocorre ao longo das trilhas no interior da mata da Vila 5. Encontrada fértil em julho. Dentre as espécies ocorrentes na área de estudos, poderia ser confundida apenas com $D$. aequivaginatum, conforme discussão dessa espécie.

3. Digitaria Haller, Hist. Stirp. Helv. 2: 244. 1768.

O gênero Digitaria inclui 300 espécies distribuídas em regiões tropicais e subtropicais de ambos os hemisférios (Canto-Dorow 2001). Na Lista da Flora do Brasil foram citadas 39 espécies (Canto-Dorow 2012). Na área de estudos, o gênero está representado por apenas uma espécie.

3.1. Digitaria insularis (L.) Fedde, Just's Bot. Jahresber. 31: 778. $1904 . \quad$ Fig. 3m-n, 8b

Plantas eretas; $80-100 \mathrm{~cm}$ compr. Folhas com bainhas glabras, margens não ciliadas, sésseis; lígula membranosa; lâminas $4-7 \times 0,3-0,7 \mathrm{~cm}$, 
linear-lanceoladas, ápice agudo, base atenuada, escabras na face adaxial, glabras na face abaxial. Inflorescências 15-20 cm compr., com 8-10 racemos subverticilados. Espiguetas ca. $5 \times 1 \mathrm{~mm}$, pareadas, ambas pediceladas, lanceoladas; gluma inferior reduzida, glabra; a superior subigual ao comprimento da espigueta, 3-nervada, longamente ciliada em toda superfície; antécio inferior neutro, lema inferior lanceolado, acuminado a aristado, 5-nervado, piloso; antécio superior 3,5-4 × 0,7 $\mathrm{mm}$, lanceolado, acuminado, glabro, papiloso, castanho escuro na maturação, com margens do lema expandidas e hialinas envolvendo a pálea. Cariopse ca. 1,8 mm compr., castanha, sem manchas.

Material selecionado: Ituberá, Mata da Pancada Grande, 26.XII.2007, fl., R.P. Oliveira 1406 (HUEFS).

Digitaria insularis é encontrada desde os Estados Unidos até a Argentina (Renvoize 1984). Ocorre nas trilhas do interior do remanescente da Pancada Grande, próximo a clareiras. Encontrada fértil em dezembro. Difere das demais espécies da área de estudos pelo antécio com as margens do lema expandidas e hialinas, envolvendo a pálea.

4. Homolepis Chase, Proc. Biol. Soc. Wash. 24: 146. 1911.

Homolepis inclui cinco espécies, distribuídas desde a América Central até a Argentina (Santos \& Sano 2001a). Na Lista da Flora do Brasil estão registradas cinco espécies, das quais quatro são endêmicas do Brasil (Shirasuna 2012a). Na área de estudos, está representado por uma espécie.

4.1. Homolepis aturensis (Kunth) Chase, Proc. Biol. Soc. Wash. 24: 146. 1911. Fig. 3o-r, 8c

Plantas decumbentes, 46-69 cm compr. Folhas com bainhas glabras, margens ciliadas, sésseis; lígula membranoso-ciliada; lâminas 6,713,1 × 0,7-1,5 cm, lanceoladas, ápice acuminado, base arredondada, glabras em ambas as faces. Inflorescências 6,2-8,6 cm compr., paniculadas, laxas. Espiguetas 6-6,5 × 1,5 mm, pareadas, ambas pediceladas, lanceoladas, agudas no ápice; glumas subiguais ao comprimento da espigueta, glabras; a inferior 9-nervada; a superior 3-nervada; antécio inferior neutro, lema inferior densamente piloso nas margens; antécio superior ca. $5 \times 1 \mathrm{~mm}$, lanceolado, acuminado, glabro, liso, estramíneo. Cariopse ca. $2 \mathrm{~mm}$ compr., estramínea, sem manchas.

Material selecionado: Ituberá, Mata da Pancada Grande, 1.X.2008, fl., K.M. Pimenta 158 (HUEFS). Igrapiúna. Mata da Vila 5, 20.XII.2008, fl., K.M. Pimenta 176 (HUEFS); Mata de Pacangê, 4.II.2009, fl., K.M. Pimenta 188 (HUEFS).

Homolepis aturensis é encontrada na América Central e Caribe, Bolívia, Brasil, Colômbia, Equador, Guiana Francesa, Peru e Venezuela (Zuloaga et al. 2003). Ocorre nos três remanescentes florestais estudados, sendo muito frequente tanto nos bordos quanto ao longo das trilhas no interior da floresta. Encontrada fértil praticamente durante todo o ano. Essa espécie difere das demais ocorrentes na REM por apresentar glumas subiguais ao comprimento da espigueta. Também difere de $H$. isocalycia, outra espécie desse gênero ocorrente na Bahia, por apresentar espiguetas agudas, gluma superior glabra, 7-nervada (Longhi-Wagner \& Oliveira 2002), e lema inferior piloso, principalmente nas margens.

5. Ichnanthus P. Beauv., Ess. Agrostogr.: 56. 1812. Inclui 31 espécies (Mota \& Oliveira 2012) predominantemente neotropicais (Oliveira et al. 2003; Boechat 2005). Filgueiras (2012a) indica 26 espécies desse gênero para o Brasil, e além dessas, uma nova espécie foi recentemente descrita para a Bahia (Mota \& Oliveira 2012). Na área de estudos ocorrem cinco espécies, algumas delas com ampla variação morfológica.

\section{Chave para as espécies de Ichnanthus ocorrentes na Reserva Ecológica da Michelin}

1. Antécio superior com um par de apêndices aliformes livres na base do lema.

2. Bainhas foliares densamente pilosas a lanosas, ciliadas nas margens 5.2. I. leiocarpus

2'. Bainhas foliares glabras, apenas ciliadas nas margens 5.3. I. nemoralis

1'. Antécio superior apenas com cicatrizes ou protuberâncias na base do lema.

3. Plantas eretas, 30-222 cm compr.; bainhas variegadas; pseudopecíolo 2-4,9 cm compr.; antécio superior com protuberâncias na base do lema 5.1. I. grandifolius

3'. Plantas decumbentes, 3-52 cm compr.; sésseis; antécio superior com cicatrizes na base do lema. 4. Plantas menores que $20 \mathrm{~cm}$ compr.; espiguetas com gluma inferior pilosa ....... 5.5. I. tenuis 4'. Plantas maiores que $20 \mathrm{~cm}$ compr.; espiguetas com gluma inferior glabra ..... 5.4. I. pallens 
5.1. Ichnanthus grandifolius (Döll) Zuloaga \& Soderstr., Smithsonian Contr. Bot. 59: 31. 1985.

Fig. 4a-c, 8d

Plantas eretas, 30-222 cm compr. Folhas com bainhas glabras, variegadas, atenuadas a pseudopecioladas, pseudopecíolo $2-4,9 \mathrm{~cm}$ compr.; lígula ciliada; lâminas 5-35 × 1,2-4 cm, lanceoladas, ápice acuminado, base atenuada, glabras em ambas as faces. Inflorescências 17-26,5 $\mathrm{cm}$; paniculadas, abertas. Espiguetas 3,5-5 × 1,5$2,3 \mathrm{~mm}$, pareadas, ambas pediceladas, lanceoladas; gluma inferior menor que o comprimento da espigueta, 3-nervada, pilosa no ápice; a superior subigual ao comprimento da espigueta, 5-nervada, glabra; antécio inferior estaminado; antécio superior 3-3,5 mm compr., lanceolado, agudo, com protuberâncias na base do lema, glabro, liso, verde claro. Cariopse não vista.

Material selecionado: Igrapiúna. Mata de Pacangê, 26.IV.2008, f1., R.P. Oliveira \& K.M. Pimenta 1532 (HUEFS). Ituberá. Mata da Pancada Grande, 20.XII.2008, fl., K.M. Pimenta 184 (HUEFS).

Ichnanthus grandifolius é endêmica do Brasil (Zuloaga et al. 2003), sendo citada para a Bahia por Renvoize (1984), sob o nome Panicum grandifolium Döll. Ocorre no interior dos remanescentes da Pancada Grande e Pacangê. Essa espécie é facilmente reconhecida dentre as demais Panicoideae ocorrentes na REM pelas longas folhas e pseudopecíolos, além de apresentar bainhas foliares variegadas e protuberâncias na base do lema superior.

5.2. Ichnanthus leiocarpus (Spreng.) Kunth, Revis. Gramin. 2: 507. 1831 Fig. 4d-e, 8e

Plantas decumbentes, 30-72,5 cm compr. Folhas com bainhas densamente pilosas a lanosas, margens longamente ciliadas, não variegadas, sésseis; lígula membranoso-ciliada; lâminas 7,5-18 × 2-4,5 cm, lanceoladas, ápice acuminado, base atenuada, face adaxial glabra, face abaxial pilosa a escabra. Inflorescências 20-28 cm compr., paniculadas, abertas. Espiguetas 5-5,5 × 2-3 mm, pareadas, ambas pediceladas, lanceoladas; glumas glabras; a inferior menor que o comprimento da espigueta, 3-nervada; a superior subigual ao comprimento da espigueta, 5-nervada; antécio inferior neutro; antécio superior 4-4,8 mm compr., lanceolado, agudo, com apêndices aliformes livres na base do lema, glabro, liso, castanho. Cariopse não vista.

Material selecionado: Igrapiúna, Mata da Vila 5, 27.XII.2007, fl., K.M. Pimenta 8 (HUEFS).
Ichnanthus leiocarpus é encontrada no Brasil, Guiana, Guiana Francesa, Caribe e Venezuela (Zuloaga et al. 2003). Encontrada na área de estudos apenas no interior da mata da Vila 5, próximo a rochas em local sombreado e úmido. Encontrada florida no mês de dezembro. Caracterizada pelas bainhas foliares densamente pilosas a lanosas, ciliadas nas margens, além de um longo par de alas na base do lema inferior. Muitos autores costumam considerar essa espécie como semelhante a I. nemoralis (Oliveira et al. 2003; Boechat 2005), especialmente pelas semelhanças no antécio superior. Porém, as populações de ambas as espécies encontradas na área de estudos são bem típicas, não apresentando dificuldade para identificação.

5.3. Ichnanthus nemoralis (Schrad. ex. Roem \& Schult.) Hitchcock \& Chase. Contr. U.S. Natl. Herb. 18(7): 334. $1917 . \quad$ Fig. 4f-g, $8 f$ Plantas cespitosas, $37,5-70 \mathrm{~cm}$ compr. Folhas com bainhas glabras, margens ciliadas, não variegadas, sésseis a curtamente pseudopecioladas; lígula membranoso-ciliada; lâminas 3,5-12 × 1-3,5 cm, oval-lanceoladas, ápice acuminado, base atenuada, glabras em ambas as faces. Inflorescências 9-22 cm compr.; paniculadas, abertas a congestas. Espiguetas 6-7 × 1,8-2 mm, pareadas, ambas pediceladas, lanceoladas; glumas glabras; a inferior menor que o comprimento da espigueta, 3-nervada; a superior subigual ao comprimento da espigueta, 7-nervada; antécio inferior neutro; antécio superior 4-4,7 mm compr., lanceolado, agudo, com apêndices aliformes livres na base do lema, glabro, liso, castanhoclaro. Cariopse ca. 2,5 mm compr., castanha, sem manchas.

Material selecionado: Ituberá, Mata da Pancada Grande, 22.II.2008, fl., K.M. Pimenta 46 (HUEFS).

Ichnanthus nemoralis é encontrada em Belize, Brasil, Caribe, Colômbia, Costa Rica, Guiana Francesa, Guiana, Guatamala, Honduras, México, Nicarágua, Panamá, Suriname e Venezuela (Zuloaga et al. 2003). Ocorre no interior da mata da Pancada Grande, ao longo das trilhas, fértil durante praticamente todo o ano, porém com maior número de indivíduos floridos entre dezembro e fevereiro. Apresenta um longo par de alas na base do lema superior, semelhante a I. leiocarpus, diferindo desta por caracteres vegetativos como as bainhas foliares desprovidas de pilosidade. 


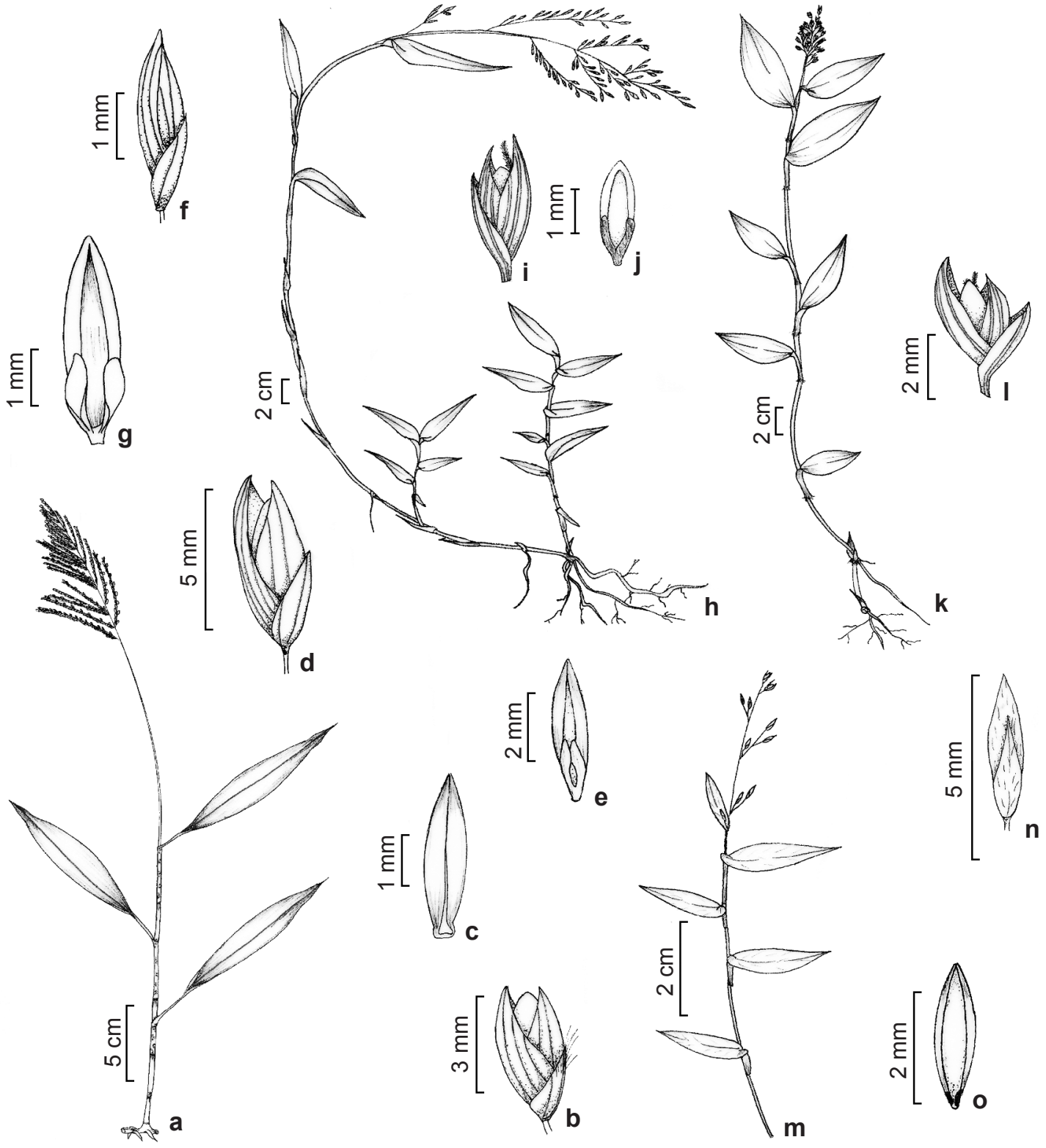

Figura 4 - a-c. Ichnanthus grandifolius (Döll) Zuloaga \& Soderstr. - a. hábito; b. espigueta; c. antécio superior, vista da pálea (K.M. Pimenta et al. 184). d-e. I. leiocarpus (Spreng) Kunth - d. espigueta; e. antécio superior, vista da pálea (K.M. Pimenta et al. 8). f-g. I. nemoralis (Schrad. ex. Roem \& Schult.) Hitchc. \& Chase - f. espigueta; g. antécio superior, vista da pálea (K.M. Pimenta et al. 46). h-j. I. pallens (Sw.) Munro ex. Benth - h. hábito; i. espigueta; j. antécio superior, vista da pálea (R.P. Oliveira et al. 1519). k-1. Morfotipos de I. pallens - k. hábito; 1. espigueta (K.M. Pimenta et al. 45). m-o. I. tenuis (J. Presl \& C. Presl) Hitchc. \& Chase - m. hábito; n. espigueta, vista da gluma inferior; o. antécio superior, vista da pálea (K.M. Pimenta et al. 115).

Figure 4 - a-c. Ichnanthus grandifolius (Doll) Zuloaga \& Soderstr. - a. habit; b. spikelet; c. upper anthecium, view of the palea (K.M. Pimenta et al. 184). d-e. I. leiocarpus (Spreng) Kunth: d. spikelet; e. upper anthecium, view of the palea (K.M. Pimenta et al. 8). f-g. I. nemoralis (Schrad. ex Roem \& Schult.) Hitchc. \& Chase - f. spikelet; g. upper anthecium, view of the palea (K.M. Pimenta et al. 46). h-j. I. pallens (Sw.) Munro ex. Benth - h. habit; i. spikelet; j. upper anthecium, view of the palea (R.P. Oliveira at al. 1519). k-1. morphotypes of I. pallens - k. habit; 1. spikelet. m-o. I. tenuis (J. Presl. \& C. Presl) Hitchc. \& Chase - m. habit; n. spikelet, view of the lower glume; o. upper anthecium, view of the palea (K.M. Pimenta et al. 115). 
5.4. Ichnanthus pallens (Sw.) Munro ex Benth, $\mathrm{Fl}$. Hongk.: 414. $1861 . \quad$ Fig. 4h-j, 8g-h

Plantas decumbentes, 29-52 cm compr. Folhas com bainhas pilosas, margens ciliadas, não variegadas, sésseis; lígula membranoso-ciliada; lâminas 2,5-7,2 × 0,8-1,5 cm, oval-lanceoladas, ápice acuminado ou agudo, base subcordada, face adaxial pilosa, face abaxial glabra. Inflorescências $3,5-8 \mathrm{~cm}$; paniculadas, abertas. Espiguetas $2-4 \times 1-1,5 \mathrm{~mm}$, pareadas, ambas pediceladas, lanceoladas, agudas no ápice; glumas glabras; a inferior menor que o comprimento da espigueta, 3-nervada; a superior subigual ao comprimento da espigueta, 5-nervada; antécio inferior neutro; antécio superior 1,8-2,2 $\mathrm{mm}$ compr., ovallanceolado, agudo, com cicatrizes na base do lema, glabro, liso, castanho. Cariopse não vista.

Material selecionado: Ituberá, Mata da Pancada Grande, 25.IV.2008, fl., R.P. Oliveira et al. 1525 (HUEFS). Igrapiúna, Mata da Vila 5, 26.X.2008, fl., K.M. Pimenta 162 (HUEFS); Mata de Pacangê, 25.IV.2009, fl., K.M. Pimenta 201 (HUEFS).

Ichnanthus pallens é encontrada na África, Índia, Austrália, sudoeste da Ásia e América (Boechat 2005). Ocorre ao longo das trilhas no interior dos três remanescentes analisados, fértil durante todo o ano. É uma das espécies com maior amplitude de variação morfológica, com vários morfotipos facilmente reconhecíveis, chegando a se sobrepor com I. tenuis (J. Presl \& C. Presl) Hitchc \& Chase em vários caracteres. Dentre os morfotipos ocorrentes na área de estudo, um concorda claramente com o modo confertus indicado por Boechat (2005) (Fig. 4k-1), mas os demais não se enquadram em nenhum morfotipo listado por essa autora, o que também foi ressaltado por Mota \& Oliveira (2011), para outra área florestal no sul da Bahia.

5.5. Ichnanthus tenuis (J. Presl \& C. Presl) Hitchc \& Chase, Contr. U.S. Natl. Herb. 18(7): 334. 1917.

Fig. $4 \mathrm{~m}-\mathrm{o}$

Plantas decumbentes, 3-14 cm compr. Folhas com bainhas pilosas, margens ciliadas, não variegadas, sésseis; lígula membranosa levemente ciliada; lâminas $1-3,2 \times 0,3-0,8$ $\mathrm{cm}$, oval-lanceoladas, ápice acuminado, base subcordada, face adaxial glabra, face abaxial pilosa. Inflorescências 2-4 cm compr., paniculadas, abertas. Espiguetas 3,5-4 × 1-1,3 mm, pareadas, ambas pediceladas, lanceoladas, agudas no ápice; glumas pilosas; a inferior menor que o comprimento da espigueta, 3-nervada; a superior subigual ao comprimento da espigueta, 5-nervada; antécio inferior neutro; antécio superior 2,3-2,5 $\mathrm{mm}$ compr., lanceolado, ápice agudo, com cicatrizes ou protuberâncias na base do lema, glabro, liso, castanho-claro. Cariopse $1,8 \mathrm{~mm}$, castanho, sem manchas.

Material selecionado: Ituberá, Mata da Pancada Grande, 26.VII.2008, fl., K.M. Pimenta 115 (HUEFS). Igrapiúna, Mata da Vila 5, 20.XII.2008, fl., K.M. Pimenta 173 (HUEFS).

Ichnanthus tenuis é encontrada desde o México até a Argentina (Boechat \& Lerina 2001). Ocorre ao longo das trilhas no interior dos três remanescentes florestais estudados, geralmente em locais mais iluminados. Foi encontrada fértil durante todo o ano. É de difícil delimitação em relação a $I$. pallens, mas em geral inclui plantas mais delicadas, com folhas e inflorescências menores.

6. Lasiacis (Griseb.) Hitchc., Contr. U.S. Natl. Herb. 15: 16. 1910.

Lasiacis inclui 20 espécies tropicais (Santos \& Sano 2001b), ocorrendo cinco espécies no Brasil (Filgueiras 2012b). Na área de estudos está representado por apenas uma espécie.

6.1. Lasiacis ligulata Hitchc. \& Chase, Contr. U.S. Natl. Herb. 18(7): 337. $1917 . \quad$ Fig. 5a-b, 8i

Plantas eretas, até $1,5 \mathrm{~m}$ compr. Folhas com bainhas glabras, margens ciliadas, sésseis; lígula membranoso-ciliada; lâminas 4,7-12,5 ×0,4-2 cm, lanceoladas, ápice agudo, base subcordada, pilosas em ambas as faces. Inflorescências $10 \mathrm{~cm}$ compr., paniculadas, abertas. Espiguetas $4 \mathrm{~mm}$ compr., pareadas, ambas pediceladas, obovais, oblíquas nos pedicelos; glumas glabras, menores que o comprimento da espigueta; a inferior 10-nervada; a superior 11-nervada; antécio inferior neutro; antécio superior 2,8-3 × 1,5 mm, oval, ápice obtuso, tomentoso, liso, estramíneo. Cariopse não vista.

Material selecionado: Ituberá, Mata da Pancada Grande, 2.VIII.2008, f1., R.P. Oliveira 1570 (HUEFS). Igrapiúna, Mata da Vila 5, 17.VIII.2008, fl., R.P. Oliveira 1381 (HUEFS).

Lasiacis ligulata é encontrada na Bolívia, Brasil, Caribe, Colômbia, Equador, Guiana Francesa, Guiana, Peru, Suriname e Venezuela (Zuloaga et al. 2003). Ocorre nos remanescentes da Pancada Grande e Mata da Vila 5, geralmente nos bordos, ou quando no interior, sempre associada a clareiras nas trilhas. Foi encontrada fértil de julho a outubro. Lasiacis ligulata pode 

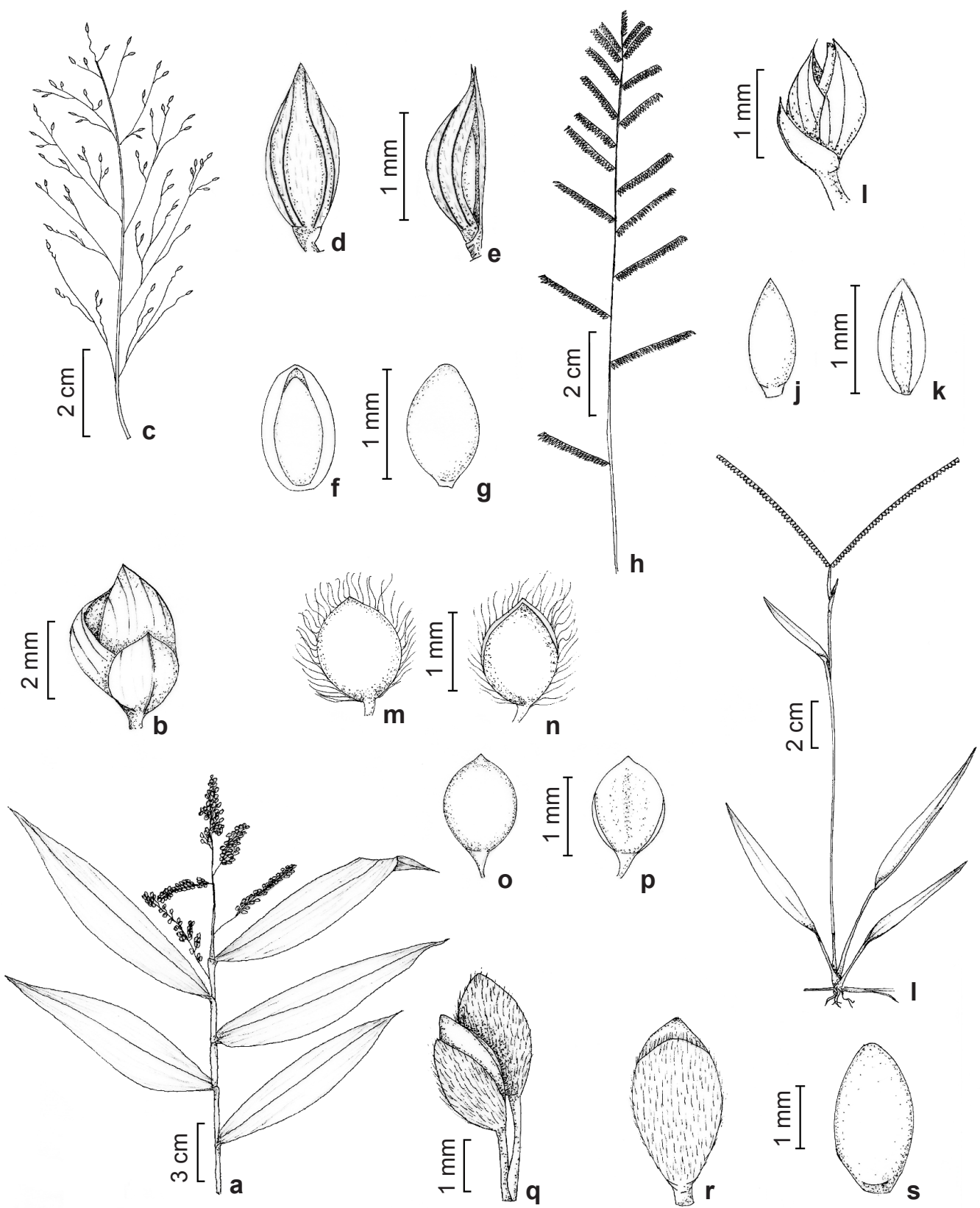

Figura 5 - a-b. Lasiacis ligulata Hitchc. \& Chase - a. ramo; b. espigueta (R.P. Oliveira 1570). c-g. Panicum brevifolium L. - c. inflorescência; d. espigueta, vista da gluma inferior; e. espigueta, vista lateral; f. antécio superior, vista da pálea; g. antécio superior, vista do lema (K.M. Pimenta et al. 155). h-k. P. pilosum Sw.: h. inflorescência; i. espigueta; j. antécio superior, vista do lema; k. antécio superior, vista da pálea (R.P. Oliveira et al. 1401). 1-p. Paspalum conjugatum P. J. Bergius - 1. hábito; m. espigueta, vista da gluma inferior; $n$. espigueta, vista da gluma superior; o. antécio superior, vista da pálea; $p$. antécio superior, vista do lema (K.M. Pimenta et al. 18). q-s. P. corcovadense Raddi-q. par de espiguetas; r. espigueta, vista da gluma inferior superior; s. antécio superior, vista do lema (K.M. Pimenta et al. 20).

Figure 5 - a-b. Lasiacis ligulata Hitchc. \& Chase - a. branch; b. spikelet (R.P. Oliveira 1570). c-g. Panicum brevifolium L. - c. inflorescence; d. spikelet, view of the lower glume; e. spikelet, side view; f. upper anthecium, view of the palea; g. upper anthecium, view of the lemma (K.M. Pimenta et al. 155). h-1. P. pilosum Sw. - h. inflorescence; i. spikelet; j. upper anthecium, view of the lemma; k. upper anthecium, view of the palea (R.P. Oliveira et al. 1401). 1-p. Paspalum conjugatum P. J. Bergius-1. habit; m. spikelet, view of the lower glume; n. spikelet, view of the upper glume; o. upper anthecium, view of the palea; $\mathrm{p}$. upper anthecium, view of the lemma (K.M. Pimenta et al. 18). q-s. P. corcovadense Raddi - q. pair of spikelets; r. spikelets, view of the lower glume; s. upper anthecium, view of the lemma (K.M. Pimenta et al. 20). 
ser confundida com L. divaricata (L.) Hitchc., mas é diferenciada principalmente pela lígula, muito maior em L. ligulata (Mota 2009). Na REM, diferencia-se das demais espécies pelas espiguetas oblíquas nos pedicelos.

7. Orthoclada P.Beauv. \& C.E.Hubb. P1. 35: 3419. 1940.

Orthoclada inclui duas espécies, ocorrendo apenas uma no Brasil (Filgueiras 2012c), presente nos remanescentes florestais da REM.

7.1. Orthoclada laxa P. Beauv., Ess. Agrostogr. 69: t. 14 , f. 70.1812.

Fig. 7p-r, 9a-b

Plantas cespitosas, $25-126 \mathrm{~cm}$ compr. Folhas com bainhas escabras, margens não ciliadas, pseudopecioladas; lígula membranoso-ciliada; lâminas 5,5-13 × 1,2-2,1 cm, lanceoladas, ápice agudo, base assimétrica, glabras em ambas as faces. Inflorescências ca. $17 \mathrm{~cm}$ compr., paniculadas, ovóides. Espiguetas 5,7-6,2 × 1,5 mm, pareadas, ambas pediceladas, lanceoladas, curtamente aristadas; glumas menores que o comprimento da espigueta; a inferior 3-nervada, escabra no ápice; a superior 5-nervada, escabra no ápice e sobre a nervura central; antécio inferior estaminado, suspenso por uma extensão da ráquila; antécio superior 3-3,2 ×0,3 mm, lanceolado, agudo, glabro, liso, castanho-claro. Cariopse ca. $3 \times 0,5$ $\mathrm{mm}$, castanha, sem manchas.

Material selecionado: Igrapiúna, Mata da Vila 5, 27.XII.2007, fl., K.M. Pimenta 2 (HUEFS); Mata de Pacangê, 30.IX.2008, fl., K.M. Pimenta 135 (HUEFS). Ituberá, Mata da Pancada Grande, 23.V.2008, fl., K.M. Pimenta 56 (HUEFS).

Orthoclada laxa é encontrada desde o México até o Brasil (Renvoize 1984). Ocorre no interior dos remanescentes da Vila 5 e Pacangê, em áreas bastante sombreadas e pouco alteradas. Foi encontrada fértil durante todo o ano. Difere das demais espécies da área de estudo principalmente pela lâmina foliar conspicuamente pseudopeciolada, além da marcada presença de antécio inferior fértil, suspenso por uma extensão da ráquila.

\section{Panicum L., Sp. Pl. 1: 55. 1753.}

Gênero considerado tradicionalmente como um dos maiores de Poaceae, mas sua delimitação tem sido alvo de mudanças frequentes, em especial na última década, sendo hoje aceitas ca. 100 espécies (Aliscioni et al. 2003). Para o Brasil foram registradas 71 espécies (Guglieri \& Rodrigues 2012), das quais apenas duas ocorrem na área de estudos.

\section{Chave para espécies de Panicum ocorrentes na Reserva Ecológica da Michelin}

1. Lâmina foliar oval; lígula membranoso-ciliada; inflorescência paniculada, aberta

8.1. P. brevifolium

1'. Lâmina foliar linear-lanceolada; lígula ausente; inflorescência com ramos contraídos unilaterais 8.2. P. pilosum

8.1. Panicum brevifolium L., Sp. Pl. 1: 59. 1753.

Fig. $5 \mathrm{c}-\mathrm{g}$

Plantas decumbentes, $40-50 \mathrm{~cm}$ compr. Folhas com bainhas glabras, margens ciliadas, sésseis; lígula membranoso-ciliada; lâminas 3,6-8 × 1,3-1,8 cm, ovais, ápice acuminado, base subcordada, face adaxial escabra, face abaxial glabra a esparsamente pilosa. Inflorescências 9,5-13,5 cm compr., paniculadas, abertas. Espiguetas 1,5-1,7 × $1 \mathrm{~mm}$, pareadas, ambas pediceladas, ovais; glumas menores que o comprimento da espigueta, glabras; a inferior 3-nervada; a superior 5-nervada; antécio inferior neutro; antécio superior $1-1,3 \times 0,7 \mathrm{~mm}$, oval, agudo, glabro, liso, estramíneo. Cariopse ca. $0,05 \mathrm{~mm}$ compr., estramínea, com mancha castanha na base e no ápice.
Material selecionado: Ituberá, Mata da Pancada Grande, 1.X.2008, fl., K.M. Pimenta 155 (HUEFS). Igrapiúna, Mata de Pacangê, 26.IV.2008, fl., R.P. Oliveira 1529 (HUEFS).

Panicum brevifolium é uma espécie introduzida, nativa dos trópicos do Velho Mundo (Renvoize 1984). Ocorre no interior dos remanescentes da Pancada Grande e Pacangê, ao longo das trilhas. Encontrada fértil durante todo o ano. Difere de P. pilosum Sw., por apresentar inflorescências paniculadas com ramos de até terceira ordem, e pela presença de lígula, ausente em P. pilosum. Essa espécie pertencia a Panicum sect. Parvifolia (Aliscioni et al. 2003), que recentemente foi elevada ao gênero Trichanthecium Zuloaga \& Morrone (Zuloaga et al. 2011). Entretanto, $P$. brevifolium não foi confirmada 
como parte desse novo gênero, permanecendo a mesma incertae sedis dentro de Panicum. Na REM difere das demais espécies pela lâmina foliar oval e inflorescência paniculada, aberta.

\subsection{Panicum pilosum Sw., Prodr.: 22. 1788.}

Fig. 5h-k, 9c

Plantas estoloníferas; 31-43 cm compr. Folhas com bainhas glabras, margens glabras, sésseis; lígula ausente; lâminas 3,5-20,2 × 0,4-1,2 cm, linearlanceoladas, ápice agudo, base subcordada, glabras em ambas as faces. Inflorescências 7-11 cm compr., com ramos unilaterais contraídos. Espiguetas ca. 1 $\times 0,4 \mathrm{~mm}$, pareadas, ambas pediceladas, elípticas; glumas menores que o comprimento da espigueta; glumas escabras no ápice da nervura central; a inferior menor que o comprimento da espigueta, 3-nervada; a superior subigual ao comprimento da espigueta, 5-nervada; antécio inferior neutro; antécio superior $1-1,3 \times 0,5 \mathrm{~mm}$, elíptico, agudo, escabro apenas no ápice, estramíneo. Cariopse não vista.
Material selecionado: Ituberá, Mata da Pancada Grande, 26.XII.2007, fl., R.P. Oliveira 1401 (HUEFS). Igrapiúna, Mata de Pacangê, 26.IV.2008, fl., R.P. Oliveira 1527 (HUEFS); Mata da Vila 5, 24.I.2008, fl., K.M. Pimenta 37 (HUEFS).

Panicum pilosum é encontrada desde o México até a Argentina, associada às áreas abertas ou sombreadas (Renvoize 1984). É uma das espécies de Panicoideae mais comuns no interior dos três remanescentes estudados, ocorrendo ao longo das trilhas, geralmente em clareiras. Foi encontrada fértil durante todo o ano. É caracterizada principalmente pela ausência de lígula, presente em todas as espécies encontradas na área de estudo.

9. Paspalum L., Syst. Nat. ed 10: 855. 1759.

Paspalum é um dos maiores gêneros de Poaceae, incluindo 310 espécies (Zuloaga et al. 2003), distribuídas em áreas tropicais e subtropicais. $\mathrm{Na}$ Lista da Flora do Brasil estão registradas 203 espécies (Valls \& Oliveira 2012), das quais oito foram encontradas na área de estudos.

\section{Chave para espécies de Paspalum ocorrentes na Reserva Ecológica da Michelin}

1. Gluma inferior presente.

2. Gluma inferior de cada par de espiguetas diferenciada quanto ao comprimento

2 '. Gluma inferior de cada par de espiguetas similar

9.3. P. decumbens

Gluma inferior ausente.

3. Inflorescência com 1-2 ramos.

4. Plantas estoloníferas; inflorescência com 2 ramos conjugados; espiguetas solitárias; antécio superior oval 9.1. P. conjugatum

4'. Plantas cespitosas; inflorescência com 1-2 ramos alternos; espiguetas pareadas; antécio superior elíptico 9.5. P. molle

3'. Inflorescência com 3 ou mais ramos.

5. Antécio superior castanho-escuro ou castanho 9.8. P. virgatum

5. Antécio superior estramíneo.

6. Folhas atenuadas na base; antécio superior elíptico 9.2. P. corcovadense

6'. Folhas não atenuadas na base; antécio superior oboval.

7. Plantas 18,5-38 cm compr.; inflorescência com 6-13 ramos; espiguetas 1,2-1,5 mm compr. 9.6. P. paniculatum

7'. Plantas ca. 135 cm compr.; inflorescência com 20-25 ramos; espiguetas 1,5-2 mm compr. 9.4. P. millegrana

9.1. Paspalum conjugatum P.J. Bergius, Acta Helv. Phys.-Math. 7: 129, t. 8. $1772 . \quad$ Fig. 51-p, 9d

Plantas estoloníferas, $11-13 \mathrm{~cm}$ compr. Folhas com bainhas glabras, margens ciliadas, sésseis; lígula membranosa; lâminas 3,5-12,5 $\times 0,4-1,1 \mathrm{~cm}$, lanceoladas, ápice agudo, base levemente atenuada ou arredondada, glabras em ambas as faces. Inflorescências 6,2-9 cm compr., racemosas, 2 ramos unilaterais conjugados. Espiguetas 1,5-1,8 $\times 1 \mathrm{~mm}$, solitárias, pediceladas, plano-convexas; gluma inferior ausente; a superior subigual ao comprimento da espigueta, 
2-nervada, longamente ciliada nas margens; antécio inferior neutro; antécio superior 1,5-1,8 $\times$ $1 \mathrm{~mm}$, oval, apiculado, glabro, liso, estramíneo. Cariopse não vista.

Material selecionado: Igrapiúna, Mata da Vila 5, 27.I.2007, fl., K.M. Pimenta 18 (HUEFS). Ituberá. Mata da Pancada Grande, 26.XII.2007, f1., R.P. Oliveira et al. 1404 (HUEFS). Igrapiúna, Mata de Pacangê, 14.II.2009, fl., K.M. Pimenta 191 (HUEFS).

Paspalum conjugatum provavelmente é nativa da América, encontrada em toda a região tropical (Oliveira \& Valls 2001). Ocorre nos três remanescentes estudados, ao longo das trilhas no interior das florestas. Foi encontrada fértil durante todo o ano. É facilmente reconhecida pelas inflorescências com dois racemos digitados, os quais incluem espiguetas solitárias.

\subsection{Paspalum corcovadense Raddi, Agrostogr.} Bras. 2: 27. 1823.

Fig. 5q-s, 9e

Plantas cespitosas, $15-26 \mathrm{~cm}$ compr. Folhas com bainhas glabras, margens ciliadas, sésseis; lígula membranosa; lâminas 7-22 × 0,8-1,1 cm, lanceoladas, ápice agudo, base atenuada, glabras em ambas as faces. Inflorescências 1,6-8,5 cm compr., racemosas, 3-6 ramos unilaterais. Espiguetas 2-2,5 $\times 1 \mathrm{~mm}$, pareadas, ambas pediceladas, planoconvexas; gluma inferior ausente; a superior menor que o comprimento da espigueta, 3-nervada, pilosa; antécio inferior neutro; antécio superior $2 \times 1-1,3$ $\mathrm{mm}$, elíptico, ápice agudo, glabro, liso, estramíneo. Cariopse não vista.

Material selecionado: Igrapiúna, Mata da Vila 5, 27.XII.2008, fl., K.M. Pimenta \& R.P. Oliveira 20 (HUEFS). Ituberá, Mata da Pancada Grande, 1.X.2008, fl., K.M. Pimenta 156 (HUEFS).

Paspalum corcovadense é encontrada em regiões tropicais e subtropicais da América do Sul (Oliveira \& Valls 2001). Ocorre nos bordos e em clareiras no interior dos remanescentes da Pancada Grande e Vila 5, encontrada fértil durante todo o ano. É facilmente reconhecida pelas folhas atenuadas na base, com claro estreitamento em direção à bainha.

9.3. Paspalum decumbens Sw., Prodr.: 22. 1788.

Fig. 6a-e, $9 \mathrm{f}$

Plantas decumbentes, 20-35 cm compr. Folhas com bainhas glabras a levemente pilosas, margens ciliadas, sésseis; lígula membranosa; lâminas 3-7 × 0,5-1 cm, lanceoladas, ápice agudo, base subcordada, pilosas em ambas as faces. Inflorescências 1,7-2,5 cm compr., racemosas, 1 ramo unilateral. Espiguetas 1,8-2 × 1,3-1,5 mm, pareadas, ambas pediceladas, obovais; glumas glabras; a inferior diferenciada quanto ao comprimento entre as espiguetas de cada par, 1-nervada; a superior menor que o comprimento da espigueta, 3-nervada; antécio inferior neutro; antécio superior 1,5-1,7 × 1,3-1,5 mm, globoso a oboval, agudo, glabro, papiloso, estramíneo. Cariopse não vista.

Material selecionado: Igrapiúna, Mata da Vila 5, 24.I.2008, fl., K.M. Pimenta \& R.P. Oliveira 28 (HUEFS).

Paspalum decumbens é encontrada desde a América Central (incluindo o Caribe) até o Brasil (Renvoize 1984). Ocorre no remanescente da Vila 5 , no interior da floresta, geralmente ao longo das trilhas. Foi encontrada fértil durante todo o ano. É caracterizada principalmente por apresentar racemos solitários, semelhante a P. pilosum Lam., porém as glumas inferiores das espiguetas em cada par são de tamanhos diferentes.

\subsection{Paspalum millegrana Schrad., Mant. 2:} 175.1824. Fig. 6f-i

Plantas cespitosas; $135-150 \mathrm{~cm}$ compr. Folhas com bainhas e margens glabras, sésseis; lígula membranoso-ciliada; lâminas ca. 32,5 $\times 1 \mathrm{~cm}$, linear-lanceoladas, ápice agudo, base truncada, face adaxial levemente pilosa, face abaxial glabra. Inflorescências ca. 16,5 cm compr., racemosas, 20-25 ramos unilaterais. Espiguetas $1,5-2 \times 1,5-2 \mathrm{~mm}$, pareadas, ambas pediceladas, plano-convexas; glumas glabras; a inferior ausente; a superior subigual ao comprimento da espigueta, 3-nervada; antécio inferior neutro; antécio superior 1,5-2 × 1,3-1,5 mm, oboval, cuspidado, glabro, liso, estramíneo. Cariopse não vista.

Material selecionado: Igrapiúna, Mata da Vila 5, 20.XII.2008, fl., K.M. Pimenta 178 (HUEFS).

Paspalum millegrana é encontrada desde a América Central (incluindo o Caribe) até o Brasil (Oliveira \& Valls 2001). Ocorre nos bordos do remanescente da Vila 5, em áreas sob intensa luminosidade. Encontrada fértil entre dezembro e abril. Possui muitas semelhanças morfológicas com P. densum Poir., sendo diferenciadas principalmente pela inflorescência, as quais segundo Renvoize (1984) são piramidais nessa espécie, com mais de 70 racemos, enquanto $P$. millegrana não apresenta inflorescência piramidal e seus racemos não ultrapassam o número de 50 . 


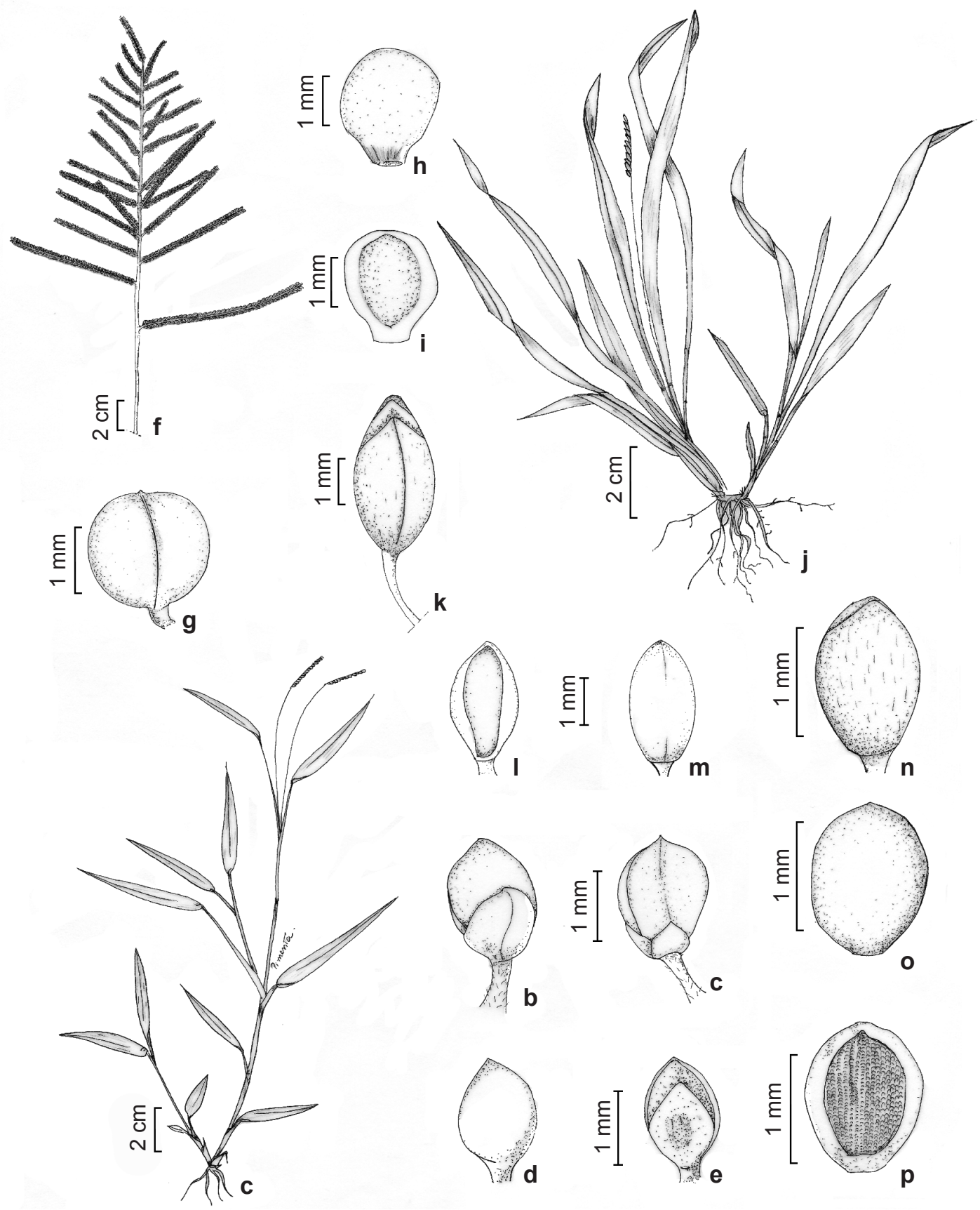

Figura 6 - a-e. Paspalum decumbens Sw. - a. hábito; b. espigueta, vista da gluma superior; c. espigueta, vista da gluma inferior; d. antécio superior, vista do lema; e. antécio superior, vista da pálea (K.M. Pimenta et al. 22). f-i. P. millegrana Schrad-f. inflorescência; g. espigueta, vista da gluma superior; h. antécio superior, vista do lema; i. antécio superior vista da pálea (K.M. Pimenta et al. 178). $\mathrm{j}-\mathrm{m}$. P. molle Poir - j. hábito; $\mathrm{k}$. espigueta vista da gluma superior; 1 . antécio superior, vista do pálea; $\mathrm{m}$. antécio superior, vista da lema (K.M. Pimenta et al. 60). n-p. P. paniculatum L. - n. espigueta, vista da gluma superior; o. antécio superior, vista do lema; $\mathrm{p}$. antécio superior, vista da pálea (K.M. Pimenta et al. 11).

Figure 6 - a-e. Paspalum decumbens $\mathrm{Sw}-\mathrm{a}$. habit; b. spikelet, view of the upper glume; c. spikelet, view of the lower glume; $\mathrm{d}$. upper anthecium, view of the lemma; e. upper anthecium, view of the palea (K.M. Pimenta et al. 22). f-h. P. millegrana Schrad -f. inflorescence; g. spikelet, view of the upper glume; $\mathrm{h}$. upper anthecium, view of the lemma; i upper anthecium, view of the palea (K.M. Pimenta et al. 178). j-m. P. molle Poir -j. habit; k. spikelet, view of the upper glume; 1 upper anthecium, view of the palea; $\mathrm{m}$. upper anthecium, view of the lemma (K.M. Pimenta et al. 60). n-p. P. paniculatum L. - n. spikelet, view of the upper glume; 0 . upper anthecium, view of the lemma; p. upper anthecium, view of the palea (K.M. Pimenta et al. 11). 
9.5. Paspalum molle Poir., Encycl. 5: 34. 1804.

Fig. 6j-m

Plantas cespitosas, 6,5-11,5 cm compr. Folhas com bainhas glabras, margens pilosas, sésseis; lígula membranoso-ciliada; lâminas 3,5-14,5 × 4-7 cm, lineares, ápice agudo, base arredonda a subcordada, pilosas em ambas as faces. Inflorescências 2-3 cm compr., racemosas, 1-2 ramos unilaterais. Espiguetas 2,3-2,5 × $1 \mathrm{~mm}$, pareadas, ambas pediceladas, plano-convexas; gluma inferior ausente; a superior subigual ao comprimento da espigueta, 3-nervada, pilosa; antécio inferior neutro; antécio superior 2-2,5× $1 \mathrm{~mm}$, elíptico, agudo, glabro, liso, estramíneo. Cariopse não vista.

Material selecionado: Ituberá, Mata da Pancada Grande, 24.V.2008, fl., K.M. Pimenta 60 (HUEFS); Mata de Pacangê, 25.IV.2009, fl., K.M. Pimenta 207 (HUEFS).

Paspalum molle é encontrada no Brasil, Caribe, Colômbia, Estados Unidos e Venezuela (Zuloaga et al. 2003). Ocorre apenas no interior dos remanescentes Pancada Grande e Pacangê, ao longo das trilhas. Encontrada fértil no mês de maio. Essa espécie apresenta inflorescência com um ou dois racemos e espiguetas com antécio superior elíptico. Além disso, inclui plantas cespitosas, principal caráter que a diferencia de $P$. conjugatum (plantas estoloníferas).

9.6. Paspalum paniculatum L., Syst. Nat. (ed.10) 2: 855.1759.

Fig. 6n-p

Plantas cespitosas, $18-38 \mathrm{~cm}$ compr. Folhas com bainhas pilosas, margens ciliadas, sésseis; lígula membranoso-ciliada; lâminas 8-18,5 × 0,8$1,3 \mathrm{~cm}$, lanceoladas, ápice agudo, base subcordada, pilosas em ambas as faces. Inflorescências 4,5-8.8 cm compr., racemosas, 6-13 ramos unilaterais. Espiguetas 1,2-1,5 × 0,7-1 mm, pareadas, ambas pediceladas, plano-convexas; gluma inferior ausente; a superior subigual ao comprimento da espigueta, 3-nervada, pilosa; antécio inferior neutro; antécio superior 1,3-1,5 × 0,8-1 $\mathrm{mm}$, oboval, ápice obtuso, glabro, papiloso, estramíneo. Cariopse não vista.

Material selecionado: Ituberá, Mata da Pancada Grande, 26.XII.2007, fl., R.P. Oliveira et al. 1402 (HUEFS). Igrapiúna, Mata da Vila 5, 27.XII.2008, fl., K.M. Pimenta \& R.P. Oliveira 11 (HUEFS).

Paspalum paniculatum é encontrada na América tropical, África tropical, Austrália, Nova Guiné e Polinésia (Renvoize 1984). Ocorre no interior dos remanescentes Pancada Grande e Vila 5, em locais alterados ao longo das trilhas e em clareiras. Encontrada fértil em dezembro. Os indivíduos dessa espécie são bastante pilosos e suas inflorescências apresentam geralmente 6-13 ramos.

9.7. Paspalum pilosum Lam., Tabl. Encycl. 1: 175. 1791.

Fig. 7a-d

Plantas cespitosas, $12-29 \mathrm{~cm}$ compr. Folhas com bainhas glabras, margens ciliadas, sésseis; lígula membranoso-ciliada; lâminas $4-13 \times 0,3-0,5 \mathrm{~cm}$, lineares, ápice agudo, base subcordada, pilosas a hirsutas em ambas as faces. Inflorescências 6,3-7,5 cm compr., racemosas, 1 ramo unilateral. Espiguetas 2,8-3 $\times 1,5 \mathrm{~mm}$, pareadas, ambas pediceladas, planoconvexas; glumas glabras; a inferior menor que o comprimento da espigueta, 1-nervada; a superior subigual ao comprimento da espigueta, 5-nervada; antécio inferior estaminado; antécio superior 2,3-2,5 × 1,5 mm, elíptico, agudo, glabro, liso, estramíneo. Cariopse não vista.

Material selecionado: Ituberá, Mata da Pancada Grande, 26.XII.2007, fl., R.P. Oliveira et al. 1408 (HUEFS).

Paspalum pilosum é encontrada desde a América Central até Bolívia e Brasil (Oliveira \& Valls 2001). Ocorre na área de estudos no interior do remanescente da Pancada Grande, em locais iluminados ao longo das trilhas. Encontrada fértil em dezembro. Essa espécie pode ser reconhecida principalmente pelos racemos solitários e espiguetas pareadas, cujas glumas inferiores são similares entre as espiguetas de cada par. Além disso, é a única espécie desse gênero que apresenta antécio inferior estaminado, dentre as que ocorrem na área de estudos.

9.8. Paspalum virgatum L., Syst. Nat. (ed. 10) 2: 855. 1759.

Fig. 7e-h, 9g

Plantas cespitosas; 80-130 cm compr. Folhas com bainhas glabras, margens ciliadas, sésseis; lígula membranoso-ciliada; lâminas $30-46 \times 1,5-2 \mathrm{~cm}$, linear-lanceoladas, ápice agudo, base truncada, glabras ambas as faces. Inflorescências 18,5-19 cm compr., racemosas, 10-15 racemos unilaterais. Espiguetas 2,8-3,2 × 1,5-2 mm, pareadas, ambas pediceladas, plano-convexas; gluma inferior ausente; a superior subigual ao comprimento da espigueta, 5-nervada, pilosa; antécio inferior neutro; antécio superior 2,3-2,8 × 1,5-1,8 mm, oboval, ápice agudo, glabro, papiloso, castanho escuro. Cariopse não vista.

Material selecionado: Igrapiúna, Mata da Vila 5, 27.XII.2007, fl., K.M. Pimenta 23 (HUEFS). 

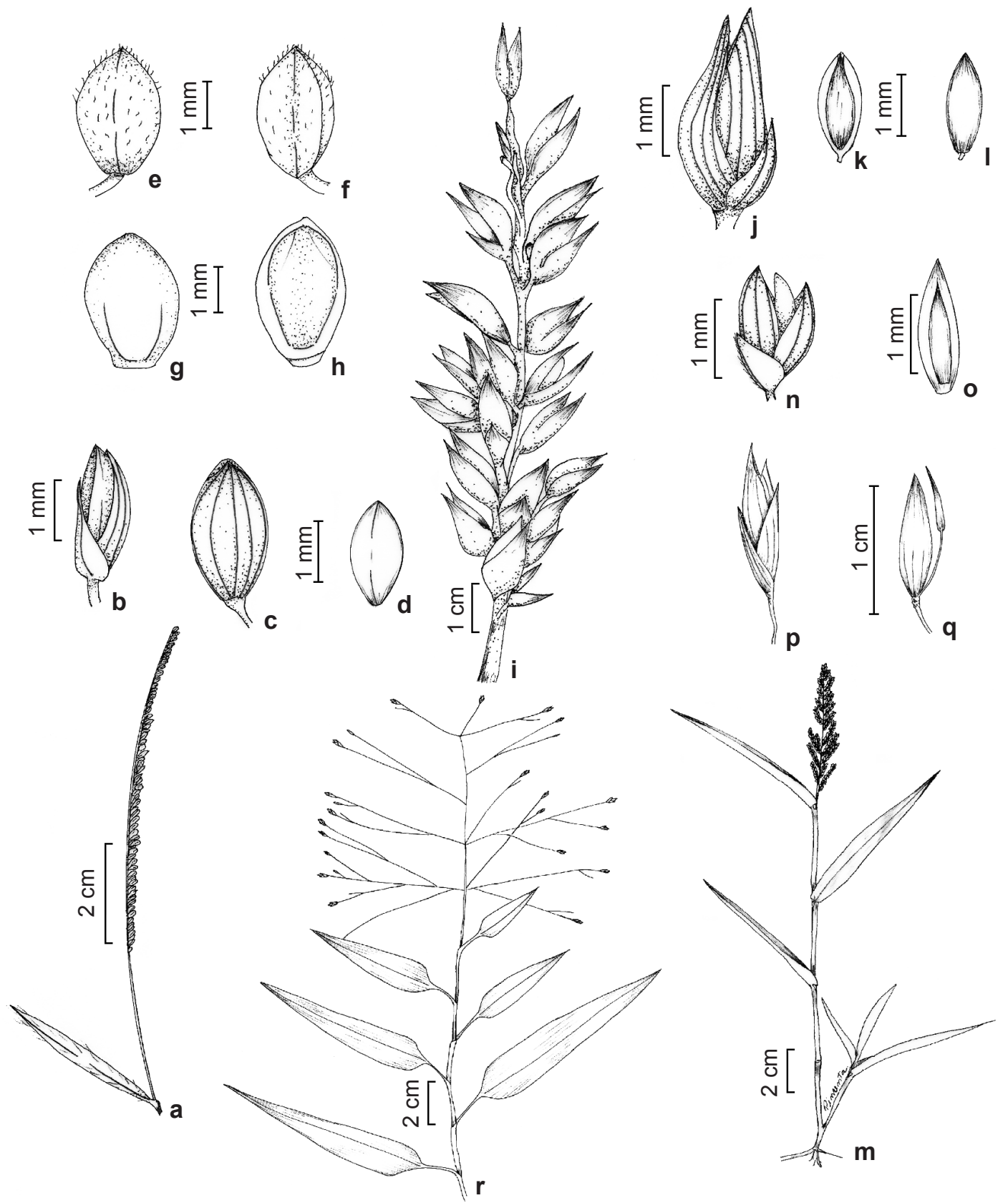

Figura 7 -a-d. Paspalum pilosum Lam. -a. inflorescência; b. espigueta, vista lateral; c. espigueta, vista da gluma superior; d. antécio superior, vista do lema (R.P. Oliveira 1408). e-h. P. virgatum L. - e. espigueta, vista da gluma superior; f. espigueta, vista do lema inferior; g. antécio superior, vista da lema; h. antécio superior, vista da pálea (K.M. Pimenta et al. 23). i-1. Sacciolepis indica (L.) Chase - $\mathrm{i}$. inflorescência; $\mathrm{j}$. espigueta, vista lateral; $\mathrm{k}$. antécio superior, vista da pálea; 1 . antécio superior, vista do lema (R.P. Oliveira 1405). m-o. Steinchisma laxa (Sw.) Zuloaga - m. hábito; $n$. espigueta, vista lateral; o. antécio superior, vista da pálea (R.P. Oliveira 1407). p-r. Orthoclada laxa P. Beauv. - p. hábito, ramo com inflorescência; q. espigueta; r. antécios (K.M. Pimenta et al. 135).

Figure 7 - a-d. Paspalum pilosum Lam - a. inflorescence; b. spikelet, view of the side lateral; c. spikelet, view of the upper glume; $d$. upper anthecium, view of the lemma (R.P. Oliveira 1408). e-h.P. virgatum L. - e. spikelet, view of the upper glume; f. spikelet, view of the lower lemma; g. upper anthecium, view of the lemma; $h$. upper anthecium, view of the palea (K.M. Pimenta et al. 23). i-1. Sacciolepis indica (L.) Chase-i. inflorescence; . spikelet, view of the lateral; $k$. upper anthecium, view of the lemma; 1 . upper anthecium, view of the palea (K.M. Pimenta et al. 23). m-o. Steinchisma laxa (Sw.) Zuloaga $-\mathrm{m}$. habit; $\mathrm{n}$. upper anthecium, view of the lemma; o. upper anthecium, view of the palea (R.P. Oliveira 1407). p-r. Orthoclada laxa P. Beauv. - p. habit; q. spikelet; r. anthecia (K.M. Pimenta et al. 135). 

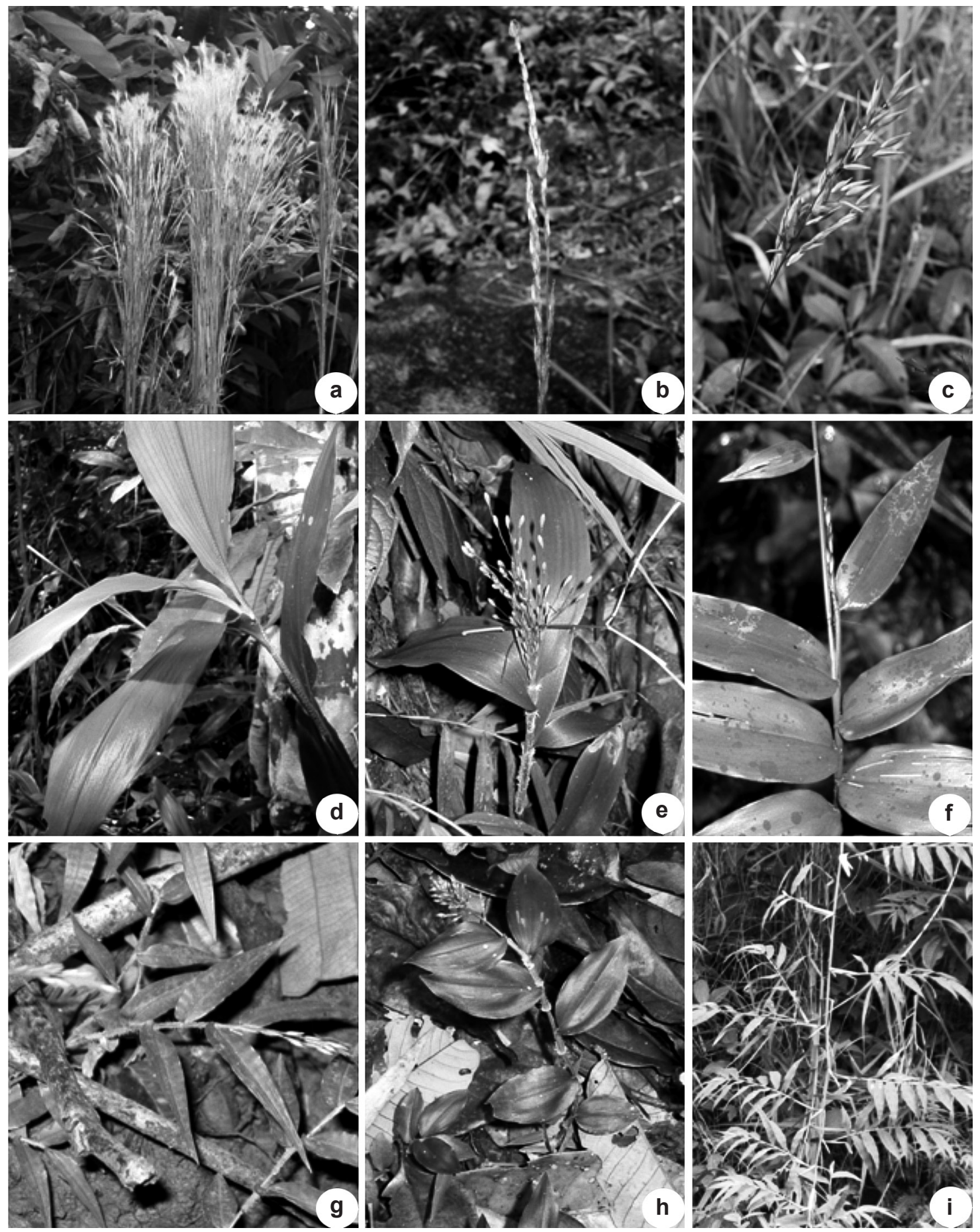

Figura 8 - a. Andropogon bicornis L. B. Digitaria insularis (L.) Fedde; c. Homolepis aturensis (Kunth) Chase; d. Ichnanthus grandifolius (Döll) Zuloaga \& Soderstr; e. I. leiocarpus (Spreng) Kunth.; f. I. nemoralis Schrad. ex. Roem \& Schult.) Hitchc. \& Chase; g-h. I. pallens (Sw.) Munro ex. Benth; i. Lasiacis ligulata Hitchc. \& Chase.

Figure 8 - a. Andropogon bicornis L. B. Digitaria insularis (L.) Fedde; c. Homolepis aturensis (Kunth) Chase; D. Ichnanthus grandifolius (Döll) Zuloaga \& Soderstr. E. I. leiocarpus (Spreng) Kunth. F. I. nemoralis Schrad. ex. Roem \& Schult.) Hitchc. \& Chase. g-h. I. pallens (Sw.) Munro ex. Benth.; i. Lasiacis ligulata Hitchc. \& Chase. 

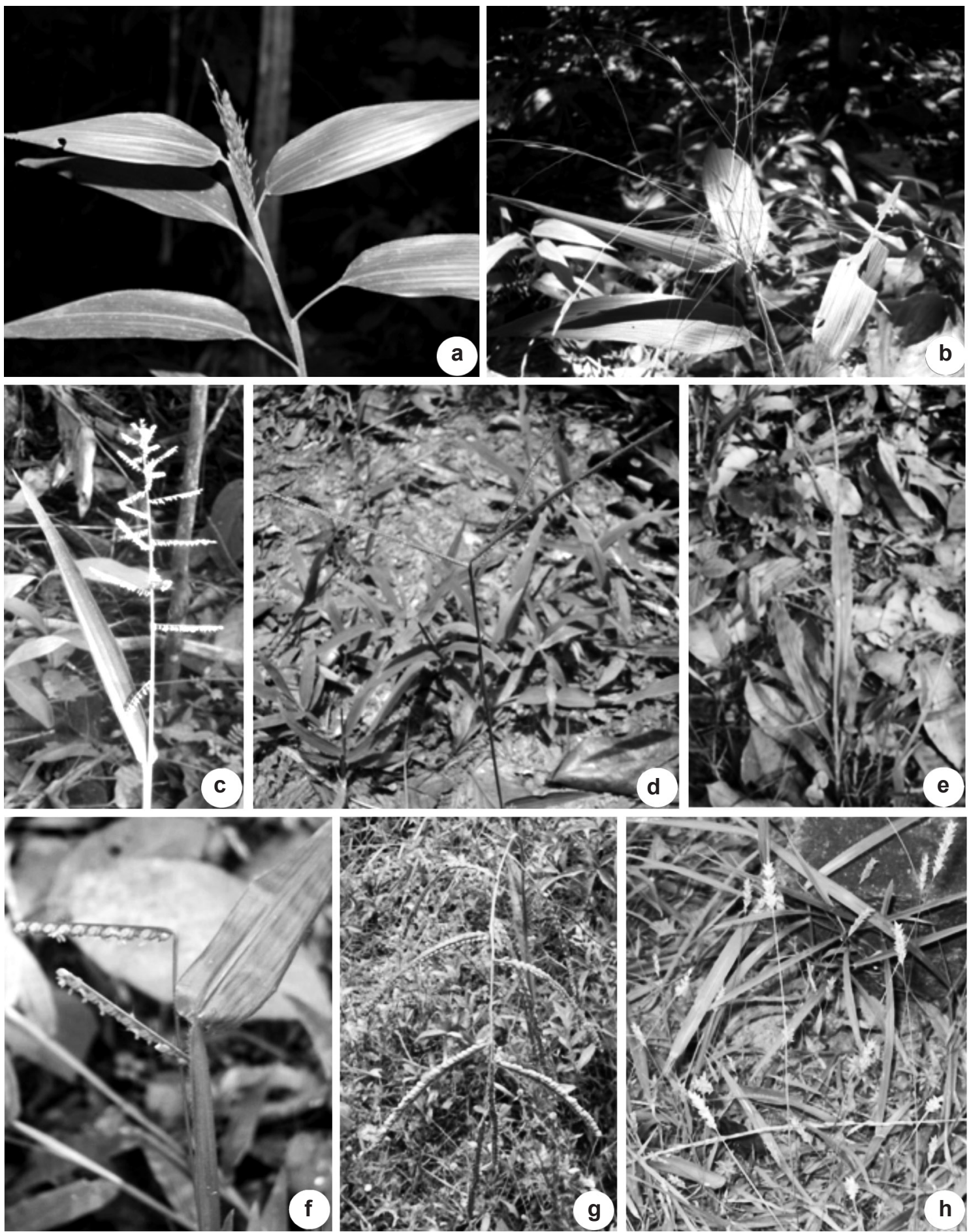

Figura 9 - a-b. Orthoclada laxa P. Beauv - c. Panicum pilosum Lam; d. Paspalum conjugatum P. J. Bergius; e. P. corcovadense Raddi; f. P. decumbens Sw; g. P. virgatum L. H. Sacciolepis indica (L.) Chase.

Figure 9 - a-b. Orthoclada laxa P. Beauv; c. Panicum pilosum Lam; d. Paspalum conjugatum P. J. Bergius; e. P. corcovadense Raddi; f. P. decumbens Sw; g. P. virgatum L. H. Sacciolepis indica (L.) Chase. 
Paspalum virgatum é encontrada desde os Estados Unidos até o Brasil (Renvoize 1984). Ocorre nos bordos do remanescente da Vila 5 , encontrada fértil de dezembro a abril. Os indivíduos dessa espécie crescem juntamente com os de P. millegrana, assemelhando-se morfologicamente quanto ao hábito. Porém, normalmente suas inflorescências são pendentes e o antécio superior é castanho-escuro ou castanho (vs. estramíneo em P. millegrana).

10. Sacciolepis Nash, Man. Fl. N. States 89. 1901. Sacciolepis inclui ca. 30 espécies tropicais de ambientes úmidos (Santos \& Sano 2001c). Na Lista da Flora do Brasil foram registradas seis espécies (Shirasuna 2012b), uma delas presente na área de estudos.

10.1. Sacciolepis indica (L.) Chase, Proc. Biol. Soc. Wash. 21: 8. $1908 . \quad$ Fig. 7i-1, 91

Plantas decumbentes, $10-30 \mathrm{~cm}$ compr. Folhas com bainhas glabras, margens glabras, sésseis; lígula membranosa; lâminas $0,8-4 \times 0,2-0,3 \mathrm{~cm}$, linearlanceoladas, ápice agudo, base arredondada, glabras em ambas as faces. Inflorescências 1-2 cm compr., paniculadas, espiciformes. Espiguetas 2,8-3 × 1-1,2 $\mathrm{mm}$ compr., pareadas, ambas pediceladas, ovallanceoladas; glumas glabras; a inferior menor que o comprimento da espigueta, 5-nervada; a superior subigual ao comprimento da espigueta, 9-nervada; antécio inferior neutro; antécio superior 1,3-1,5 × 0,5 $\mathrm{mm}$, lanceolado, ápice agudo, glabro, liso, estramíneo. Cariopse ca. $1 \mathrm{~mm}$, castanha, sem manchas.

Material selecionado: Ituberá, Mata da Pancada Grande, 26.XII.2007, fl., R.P. Oliveira 1405 (HUEFS).

Sacciolepis indica foi introduzida no Novo Mundo (Judziewicz 1990), nativa dos trópicos do Velho Mundo (Renvoize 1984). Ocorre ao longo das trilhas no interior do remanescente da Pancada Grande, e em seus bordos, em ambientes muito úmidos, próximos ao rio Cachoeira Grande. Encontrada fértil no mês de dezembro. É caracterizada principalmente pelas folhas pequenas e delicadas, além das inflorescências espiciformes.

11. Steinchisma Raf., Bull. Bot. (Geneve) 1: 220. 1830.

Steinchisma compreende seis espécies (Zuloaga et al. 2003), distribuídas dos Estados Unidos até a Argentina (Zuloaga et al. 2001). Na Lista da Flora do Brasil estão registradas cinco espécies (Shirasuna 2012c) das quais apenas uma ocorre na área de estudos.
11.1. Steinchisma laxa (Sw.) Zuloaga, Amer. J. Bot. 90: 817. 2003.

Fig. $7 \mathrm{~m}-\mathrm{o}$

Plantas cespitosas, 35-40 cm compr. Folhas com bainhas glabras, margens ciliadas, sésseis; lígula membranosa; lâminas $4-9 \times 0,6-1,3 \mathrm{~cm}$, lanceoladas, ápice agudo, base subcordada, glabras. Inflorescências ca. $10 \mathrm{~cm}$ compr., paniculadas, abertas a congestas. Espiguetas 1,5-1,7 × 0,5-0,7 $\mathrm{mm}$, pareadas, ambas pediceladas, elípticolanceoladas; glumas menores que o comprimento da espigueta; a inferior 3-nervada, escabra na nervura central; a superior 5-nervada, glabra; antécio inferior neutro, pálea inferior conspícua, expandida na maturação; antécio superior 1,3-1,5 × 0,5 mm, lanceolado, agudo, papiloso longitudinalmente, glabro, estramíneo. Cariopse não vista.

Material selecionado: Ituberá, Mata da Pancada Grande, 26.XII.2007, fl., R.P. Oliveira 1407 (HUEFS).

Steinchisma laxa é encontrada desde a América Central à Argentina (Renvoize 1984). Ocorre ao longo das trilhas no interior do remanescente da Pancada Grande, geralmente em locais mais abertos, com intensa luminosidade. Foi encontrada fértil em novembro. Poderia ser confundida com Panicum pilosum, porém diferencia-se pela arquitetura da inflorescência aberta e pálea inferior expandida na maturação em S. laxa (Mota 2009), além da presença de lígula.

Considerações ecológicas e sobre a ocorrência das espécies na REM

Dentre os gêneros de Panicoideae ocorrentes nos remanescentes florestais estudados, Paspalum foi o mais representativo, com oito espécies. Porém, Ichnanthus, além de também incluir número considerável de espécies (cinco), foi o que apresentou maior ocorrência nessas áreas, com pelo menos três espécies em duas delas. Esses dados concordam com os achados de Mota \& Oliveira (2011) para outro remanescente florestal no sul da Bahia (porém em floresta montana), onde Paspalum também aparece como o gênero mais representativo, seguido de Ichnanthus.

Dentre as espécies analisadas, 17 ocorrem na Mata da Pancada Grande, 16 na Vila 5, e apenas nove em Pacangê. Esta situação pode ser justificada pelo intenso desmatamento nesse último remanescente, que começou no início do século XIX e representa atualmente um mosaico de formações vegetacionais em regeneração.

Homolepis aturensis, Ichnanthus pallens, I. tenuis, Panicum pilosum e Paspalum conjugatum 
apresentam ampla ocorrência dentro da REM, coletadas nos três remanescentes analisados. As demais espécies foram restritas a apenas um remanescente, a exemplo de Andropogon bicornis, Dichanthelium aequivaginatum, $D$. sciurotoides, Ichnanthus leiocarpus, Paspalum decumbens, $P$. millegrana e $P$. virgatum, exclusivas da mata da Vila 5; além de Digitaria insularis, I. nemoralis, Panicum brevifolim, Paspalum pilosum, Sacciolepis indica e Steinchisma laxa, encontradas apenas em Pancada Grande. Por outro lado, nenhuma espécie de Panicoideae analisada foi coletada exclusivamente em Pacangê.

A maioria das espécies analisadas (15) ocorre exclusivamente no interior desses remanescentes, em áreas mais sombreadas. Seis ocorrem no interior e nos bordos (Dichanthelium sciurotoides, Homolepis aturensis, Lasiacis ligulata, Paspalum conjugatum, Paspalum corcovadense e Sacciolepis indica), e apenas três ocorrem exclusivamente nos bordos (Andropogon bicornis, Paspalum millegrana e $P$. virgatum).

Isso demonstra a importância da manutenção desses remanescentes para a sobrevivência dessas espécies, assim como de outros grupos de plantas que ocorrem tanto na REM quanto na Mata Atlântica como um todo.

\section{Agradecimentos}

Os autores agradecem às Plantações Michelin da Bahia Ltda., na pessoa do Dr. Kevin Flesher e da MSc. Juliana Laufer, pelo apoio incondicional à realização desse trabalho, incluindo suporte financeiro, logístico e a concessão de bolsa IC para a primeira autora; à Universidade Estadual de Feira de Santana, pelo apoio às coletas e infraestrutura disponibilizada para a identificação dos espécimes; à Fundação de Amparo à Pesquisa do Estado da Bahia, pelo auxílio financeiro (termo de outorga APR 0218/2008), e ao CNPq pelo suporte financeiro (processo 562349/2010-3). A terceira autora também agradece ao $\mathrm{CNPq}$ pela bolsa de produtividade em pesquisa (PQ2) concedida.

\section{Referências}

Aliscioni, S.S.; Giussani, L.M.; Zuloaga, F.O. \& Kellogg, E.A. 2003. A molecular phylogeny of Panicum (Poaceae: Panicoideae): tests of monophyly and phylogenetic placement within Panicoideae. American Journal Botany 90: 796-821.

Boas-Bastos, S.B. \& Bastos, C.J. 2009. Musgos pleuropárpicos dos remanescentes de Mata Atlântica da Reserva Ecológica da Michelin, município de Igrapiúna, BA, Brasil. II-Hypnales (Bryophyta: Bryopsida). Acta Botanica Brasilica 23: 630-643.

Boechat, S.C. 2005. O gênero Ichnanthus (PoaceaePanicoideae-Paniceae) no Brasil. Iheringia, Série Botânica 60: 189-248.

Boechat, S.C. \& Lerina, R. 2001. Ichnanthus P. Beauv. In: Longhi-Wagner; H.M.; Bittrich, V.; Wanderley, M.G.L. \& Shepherd, G.J. (eds.). Poaceae - Flora fanerogâmica do estado de São Paulo. Vol. 1. Hucitec, São Paulo. Pp 157-163.

Canto-Dorow, T.S. 2001. Digitaria Haller. In: LonghiWagner; H.M.; Bittrich; V.; Wanderley; M.G.L. \& Shepherd, G.J. (eds.). Poaceae - Flora fanerogâmica do estado de São Paulo. Vol. 1. Hucitec, São Paulo. Pp 143-149.

Canto-Dorow, T.S. 2012. Digitaria Haller. In: Forzza, R.C. et al. (eds.). Lista de espécies da flora do Brasil - Poaceae. Jardim Botânico do Rio de Janeiro. Disponível em $<$ http://floradobrasil.jbrj. gov.br/2012/FB013174>. Acesso em 25 Mai 2012.

Filgueiras, T.S. 2012a. Ichnanthus P. Beauv. In: Forzza, R.C. et al. (eds.). Lista de espécies da flora do Brasil. Jardim Botânico do Rio de Janeiro. Disponível em $<$ http://floradobrasil.jbrj.gov.br/2012/FB013273>. Acesso em 25 Mai 2012.

Filgueiras, T.S. 2012b. Lasiacis (Griseb.) Hitchc. In: Forzza, R.C. et al. (eds.). Lista de espécies da flora do Brasil. Jardim Botânico do Rio de Janeiro. Disponível em http://floradobrasil.jbrj.gov.br/2012/ FB013295. Acesso em 25 maio 2012.

Filgueiras, T.S. 2012c. Orthoclada P. Beauv. In: Forzza, R.C. et al. (eds.). Lista de espécies da flora do Brasil. Jardim Botânico do Rio de Janeiro. Disponível em $<$ http://floradobrasil.jbrj.gov.br/2012/FB020420>. Acesso em 25 Mai 2012.

Filgueiras, T.S.; Longhi-Wagner, H.M.; Viana, P.L.; Zanin, A.; Guglieri, A.; Oliveira, R.C.; CantoDorow, T.S.; Shirasuna, R.T.; Valls, J.F.M. \& Oliveira, R.P. 2012. Poaceae. In: Forzza, R.C. et al. (eds.). Lista de espécies da flora do Brasil. Jardim Botânico do Rio de Janeiro. Disponível em < http:// floradobrasil.jbrj.gov.br/2012/FB000193>. Acesso em 25 Mai 2012.

Giussani, L.M.; Cota-Sanchez, J.H.; Zuloaga, F.O. \& Kellogg, E. A. 2001. A molecular phylogeny of the grass subfamily Panicoideae (Poaceae) shows multiple origins of $\mathrm{C} 4$ photosynthesis. American Journal of Botany 88: 1993-2012.

GPWG (The Grass Phylogeny Working Group). 2001. Phylogeny and subfamilial classification of the grasses (Poaceae). Annals of the Missouri Botanical Garden 88: 373-457.

Guglieri, A. \& Rodrigues, R.S. 2010. Panicum L. In: Forzza, R.C. et al. (eds.). Lista de espécies da flora do Brasil. Jardim Botânico do Rio de Janeiro. Disponível em <http://floradobrasil.jbrj.gov. br/2012/FB013374>. Acesso em 25 Mai 2012. 
Judziewicz, E.J. 1990. A new South American species of Sacciolepis (Poaceae: Panicoideae: Paniceae), with a summary of the genus in the New World. Systematic Botany 15: 415-420.

Longhi-Wagner, H.M. \& Oliveira, R.P. 2002. New grass records for Bahia State, Brasil. Kew Bulletin 57: 971-977.

Longhi-Wagner, H.M. 2001. Poaceae. In: LonghiWagner, H.M.; Bittrich, V.; Wanderley M.G.L. \& Shepherd, G.J. (eds.). Poaceae - Flora fanerogâmica do estado de São Paulo. Vol. 1. Hucitec, São Paulo. $291 \mathrm{p}$.

Morrone, O.; Aagesen, L.; Scataglini, M.A.; Salariato, D.L.; Denham, S.S.; Chemisquy, M.A.; Sede, S.M.; Giussani, L.M.; Kellogg, E.A.; Zuloaga, F.O. 2012. Phylogeny of the Paniceae (Poaceae: Panicoideae): integrating plastid DNA sequences and morphology into a new classification. Cladistics. doi: 10.1111/j.1096-0031.2011.00384.x

Mota, A.C. \& Oliveira, R.P. 2011. Poaceae em uma área de floresta montana no sul da Bahia, Brasil: Chloridoideae e Panicoideae. Rodriguésia 62: 515-545.

Mota, A.C. \& Oliveira, R.P. 2012. Ichnanthus longhiwagnerii (Panicoideae): new grass from the Atlantic moist forest of Bahia, Brazil. Systematic Botany 37: 117-121.

Mota, A.C. 2009. Poaceae em uma área de floresta montana no sul da Bahia, Brasil. Dissertação de Mestrado. Universidade Estadual de Feira de Santana, Feira de Santana. 120p.

Oliveira, R.C. \& Valls, J.F.M. 2001. Paspalum L. In: Longhi-Wagner, H.M.; Bittrich, V.; Wanderley, M.G.L. \& Shepherd, G.J. (eds). Poaceae - Flora fanerogâmica do estado de São Paulo. Vol. 1. Hucitec, São Paulo. Pp. 191-228.

Oliveira, R.P. \& Longhi-Wagner, H.M. 2005. Olyra bahiensis (Poaceae, Olyreae): uma nova espécie para a Mata Atlântica do Estado da Bahia, Brasil. Revista Brasileira de Botânica 28(4): 835-839.

Oliveira, R.P. 2001. A tribo Olyreae (Poaceae: Bambusoideae) no Estado da Bahia, Brasil. Dissertação de Mestrado. Universidade Estadual de Feira de Santana, Feira de Santana. 190p.

Oliveira, R.P.; Longhi-Wagner \& Giulietti, A.M. 2003. O gênero Ichnanthus (Poaceae: Paniceae) na Chapada Diamantina, Bahia, Brasil. Acta Botanica Brasilica 17: 49-70.

Oliveira, R.P.; Longhi-Wagner, H.M.; Leite, K.R.B. \& Hollowell V.C. 2008. Pariana multiflora (Poaceae, Bambusoideae, Olyreae), a new species from Eastern Brazil, with notes on the leaf anatomy of the genus. Systematic Botany 33: 262-266.

Oliveira, R.P.; Longhi-Wagner, H.M.L. \& Hollowell, V.C. 2004. A new species of Pariana Aubl. (Poaceae, Bambusoideae, Olyreae) endemic to the
Atlantic moist forest in the State of Bahia, Brazil. Novon 14: 206-209.

Renvoize, S.A. 1984. The Grasses of Bahia. Royal Botanic Gardens, Kew, 301p.

Sánchez-Ken, J.G. \& Clark, L.G. 2010. Phylogeny and a new tribal classification of the Panicoideae s.l. (Poaceae) based on plastid and nuclear sequence data and structural data. American Journal of Botany 97: 1732-1748.

Santos, C.A.G. \& Sano, P. 2001a. Homolepis Chase. In: Longhi-Wagner, H.M.; Bittrich, V.; Wanderley, M.G.L. \& Shepherd, G.J. (eds). Poaceae - Flora fanerogâmica do estado de São Paulo. Vol. 1. Hucitec, São Paulo. Pp. 154-155.

Santos, C.A.G. \& Sano, P. 2001b. Lasiacis (Griseb.) Hitchc. In: Longhi-Wagner, H.M.; Bittrich, V.; Wanderley, M.G.L. \& Shepherd, G.J. (eds.). Poaceae - Flora fanerogâmica do estado de São Paulo. Vol. 1. Hucitec, São Paulo. Pp. 163-164.

Santos, C.A.G. \& Sano, P. 2001c. Sacciolepis Nash. In: Longhi-Wagner, H.M.; Bittrich, V.; Wanderley, M.G.L. \& Shepherd, G.J. (eds). Poaceae - Flora fanerogâmica do estado de São Paulo. Vol. 1. Hucitec, São Paulo. Pp. 232-233.

Shirasuna, R.T. 2012a. Homolepis Chase. In: Forzza, R.C. et al. (eds.). Lista de espécies da flora do Brasil. Jardim Botânico do Rio de Janeiro. Disponível em $<$ http://floradobrasil.jbrj.gov.br/2012/FB013261>. Acesso em 25 Mai 2012.

Shirasuna, R.T. 2012b. Sacciolepis Nash. In: Forzza, R.C. et al. (eds.). Lista de espécies da flora do Brasil. Jardim Botânico do Rio de Janeiro. Disponível em $<$ http://floradobrasil.jbrj.gov.br/2012/FB013572>. Acesso em 25 Mai 2012.

Shirasuna, R.T. 2012c. Steinchisma Raf. In: Forzza, R.C. et al. (eds.). Lista de espécies da flora do Brasil. Jardim Botânico do Rio de Janeiro. Disponível em <http://floradobrasil.jbrj.gov.br/2012/FB013628>. Acesso em 25 Mai 2012.

Thiers, B. 2012. Index Herbariorum: a global directory of public herbaria and associated staff. New York Botanical Garden's Virtual Herbarium. Disponível em $<$ http://sweetgum.nybg.org/ih/>. Acesso em 1 Mar 2012.

Valls, J.F.M. \& Oliveira, R.C. 2012. Paspalum L. In: Forzza, R.C. et al. (eds.). Lista de espécies da flora do Brasil. Jardim Botânico do Rio de Janeiro. Disponível em <http://floradobrasil.jbrj.gov. br/2012/FB013432>. Acesso em 25 Mai 2012.

Viana, P.L. \& Rodrigues, R.S. 2012. Dichanthelium (Hitchc. \& Chase) Gould. In: Forzza, R.C. et al. (eds.). Lista de espécies da flora do Brasil. Jardim Botânico do Rio de Janeiro. Disponível em <http:// floradobrasil.jbrj.gov.br/2012/FB013157>. Acesso em 25 Mai 2012. 
Zanin, A. 2012. Andropogon L. In: Forzza, R.C. et al. (eds.). Lista de espécies da flora do Brasil. Jardim Botânico do Rio de Janeiro. Disponível em $<$ http:// floradobrasil.jbrj.gov.br/2012/FB012955>. Acesso em 25 Mai 2012.

Zuloaga, F.O.; Guglieri, A. \& Longhi-Wagner, H.M. 2001. Steinchisma Raf. In: Longhi-Wagner, H.M.; Bittrich, V.; Wanderley, M.G.L. \& Shepherd, G.J. (eds.). Poaceae - Flora fanerogâmica do estado de São Paulo. Vol. 1. Hucitec, São Paulo. Pp. 238-239.
Zuloaga, F.O.; Morrone, O.; Davidse, G.; Filgueiras, T.S.; Peterson, P.M.; Soreng, R.J. \& Judziewicz, E.J. 2003. Catalogue of New world Grasses (Poaceae): III. Subfamilies Panicoideae, Aristidoideae, Arundinoideae and Danthonioideae. Contributions from the United States National Herbarium 46: 1-662.

Zuloaga, F.O.; Morrone, O.; Scataglini, M.A. 2011. Monograph of Trichanthecium (Poaceae, Paniceae). Systematic Botany Monographs 94: 1-98. 
